\title{
EL DESARROLLO INDUSTRIAL EN LA ARGENTINA. ANÁLISIS DESDE LA HISTORIA Y LA GEOGRAFÍA
}

Prof. María del Mar Solís Carnicer Lic. Silvia Castelán Prof. Mayra Maggio Historia Argentina Contemporánea Profesorado y Licenciatura en Historia

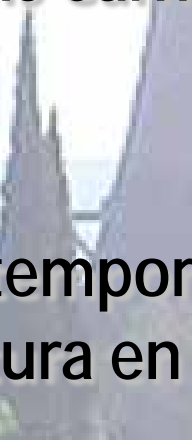

Material de consulta de cátedra elaborado a partir de la compilación de bibliografía impresa e información en Internet
Prof. Aníbal M. Mignone Prof. Alejandra H. Torre Geraldi Geografía Argentina Profesorado y Licenciatura en Geografía

$+\frac{2}{2}=4$

\section{Pos}

Seminario "El desarrollo industrial en la Argentina. Análisis desde la Historia y la Geografía".

Facultad de Humanidades. Universidad Nacional del Nordeste, 13 y 27 de mayo de 2016

Publicado en formato digital: Prof. María del Mar Solís Carnicer, Lic. Silvia Castelán, Prof. Mayra Maggio, Prof. Aníbal M. Mignone y Prof. Alejandra H. Torre Geraldi. El desarrollo industrial en la Argentina. Análisis desde la Historia y la Geografía, Producción en docencia. Revista Geográfica Digital. IGUNNE. Facultad de Humanidades. UNNE. Año 13. No 26. Julio - Diciembre 2016. Resistencia, Chaco. En: http://hum.unne.edu.ar/revistas/geoweb/default.htm 
La presentación forma parte de la exposición desarrollada en el Seminario: El desarrollo industrial en la Argentina. Análisis desde la Historia y la Geografía. Facultad de Humanidades, Universidad Nacional del Nordeste, 13 y 27 de mayo de 2016.

\section{Ente Organizador}

\section{Cátedras:}

-Historia Argentina Contemporánea (Profesorado y Licenciatura en Geografía- Departamento de Historia)

- Geografía Argentina (Profesorado y licenciatura en Geografía- Departamento de Geografía)

\section{Docentes Dictantes:}

Prof. María del Mar Solís Carnicer

Lic. Silvia Castelán

Prof. Aníbal Marcelo Mignone

Prof. Alejandra Helena Torre Geraldi

Lic. Mayra Maggio

\section{Colaboración de Adscriptos:}

Sr. Gabriel Compieque

\section{Objetivo}

Los docentes de las cátedras mencionadas, realizan la actividad para analizar el desarrollo industrial del país, permitiendo reconocer la interrelación entre los procesos históricos y geográficos que determinaron la localización, distribución y evolución de las industrias en el territorio nacional y en cada una de sus regiones. 


\section{Factores de localización industrial}

- Existencia de recursos naturales: materia prima

- El Transporte y las comunicaciones

- Provisión de fuentes de energía

- Precio del suelo

- Disponibilidad, calificación y coste de la mano de obra

- Mercado de consumo

- Calidad del medio ambiente

- Investigación e innovación

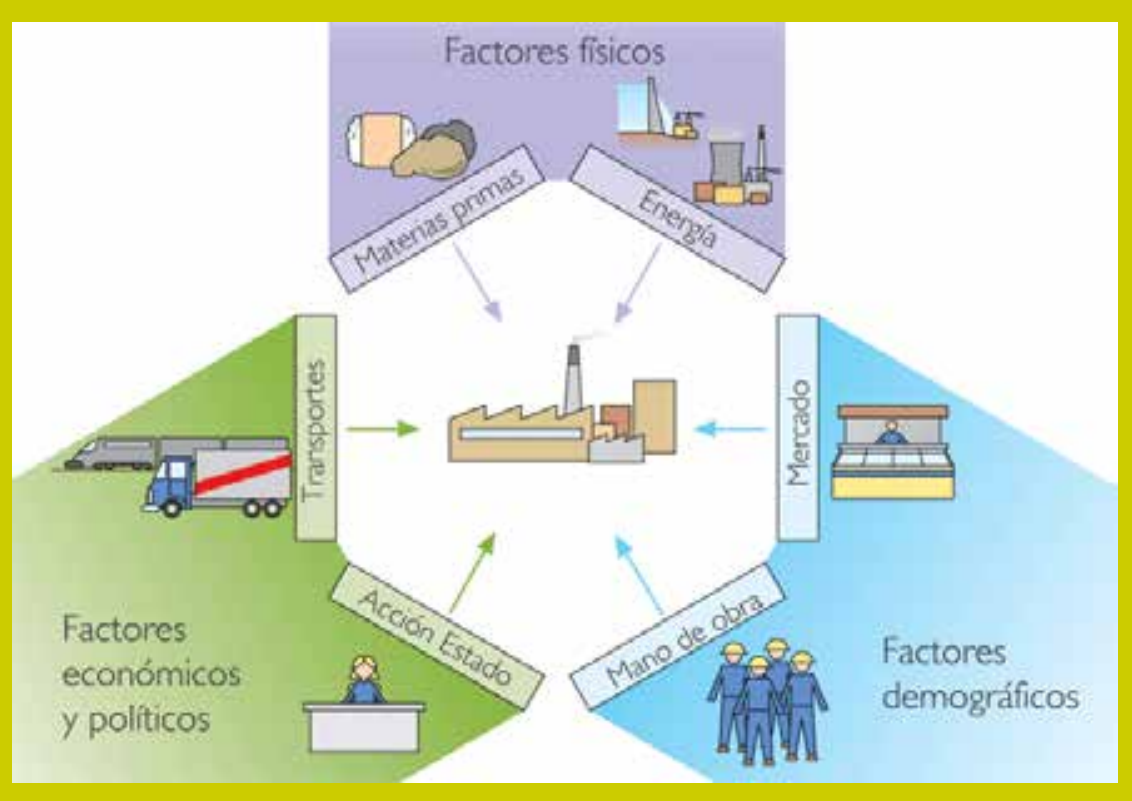

- Acción estatal: políticas industriales

Fuente: Imagen obtenida de Acércate a las Sociales, S/ F. 


\section{TIPOS DE INDUSTRIAS}

\section{CLASIFICACIÓN}

- Tamaño

- Plantas

- Capital

- Demanda

- Localización

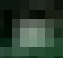

- Producción

Fuente: Negro, 1982; Carlevari, 2006. Imagen obtenida de Informe Industrial, 2012. ar Solís Carnicer, Li Análisi 26. Julio of Mayra Maggio, Prof Producción en docen Chaco. En: http://hum.
- Alimentaria

- Textil

- Siderúrgica

- Metalúrgica

- Aluminio

- Automotriz

Química

- Farmacéutica

- Celulosa y papel

- Tanino

- Caucho

- Cuero

- Construcción

- Cemento
M. Mignone y Prof. Alejandra H. Torre vista Geográfica Digital. IGUNNE. du.ar/revistas/geoweb/default.htm 
Revista Geográfica Digital „IGUNNE. Facultad de Huma hidades. UNNE. Año 13. No 26. Julio Diciemb 2016.1SSN 1668-5180. Resistencia, Chaco

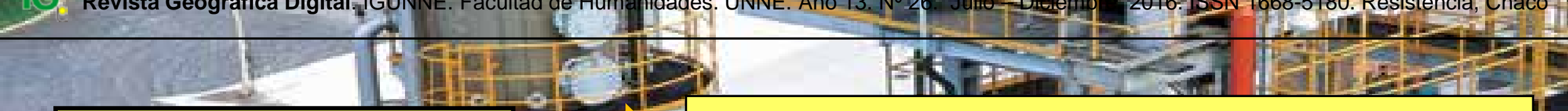

\section{Bienes de consumo}

Aptos para satisfacer en forma directa las necesidades.

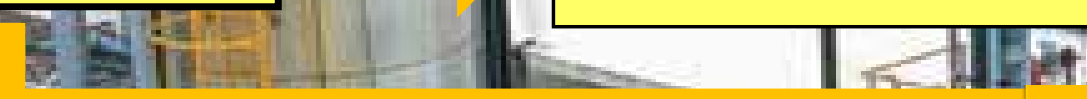

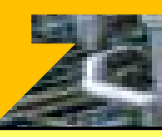

Durables: no se consumen en el primer uso: calzados, ropa, heladeras domésticas, TV.

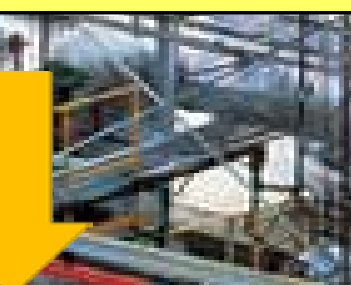

No durables: se consumen la primera vez: alimentos, bebidas.

\section{Bienes Intermedios \\ Bienes de Capital}

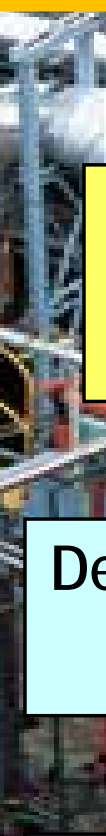

De larga duración, se acercan a los bienes de consumo durables: automóviles, tractores
Fuente: Imagen obtenida de Atanor, S/f.

Hy

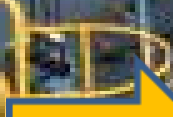

tret

2.

\section{Son los "medios de producción producidos".}

Son las máquinas y equipos para la fabricación de otros medios: tornos, altos hornos, envasadoras, heladera industrial. 


\section{TAYLORISMO}

ß Fue un antecedente del "fordismo"

ß Se centra en el estudio de la organización interna de la fábrica.

ß Conjunto de reglas y principios de la organización industrial, para mejorar su capacidad de producción.

ß Trata de aprovechar la actividad del operario con el menor esfuerzo.

\section{FORDISM 0}

ß Creación de cadena o línea de montaje. B Se reduce el tiempo de trabajo: crece la productividad.

ß Baja de precios: Incremento de la demanda y aumento del consumo.

B Se desarrolla en la postguerra y perdura hasta la década del 70.

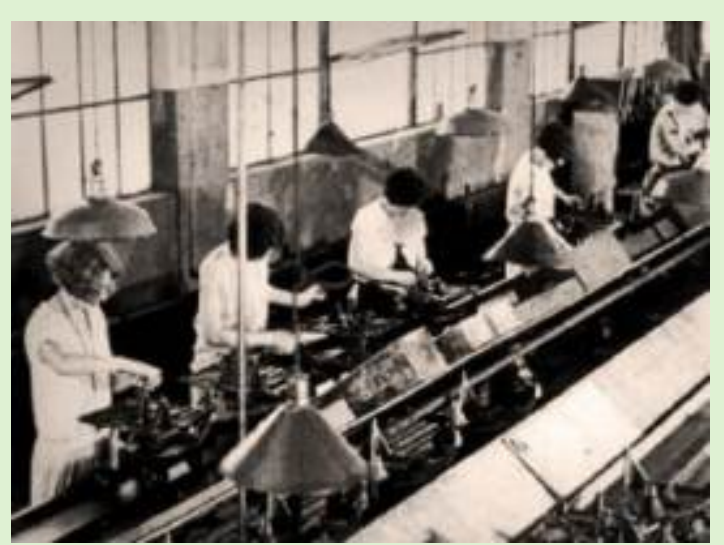

Fuente: Imagen obtenida de Diccionario 2. 08/ 08/ 2013

Fuente: Pelaez,1997:145- 151

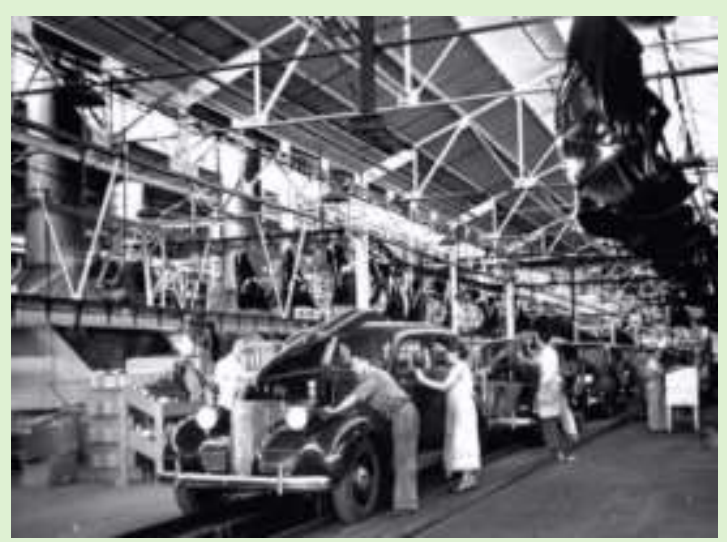

Fuente: Imagen obtenida de Cortes de Cádiz. 2015

Publicado en formato digital: Prof. María del Mar Solís Carnicer, Lic. Silvia Castelán, Prof. Mayra Maggio, Prof. Aníbal M. Mignone y Prof. Alejandra H. Torre Geraldi. El desarrollo industrial en la Argentina. Análisis desde la Historia y la Geografía, Producción en docencia. Revista Geográfica Digital. IGUNNE. Facultad de Humanidades. UNNE. Año 13. № 26. Julio - Diciembre 2016. Resistencia, Chaco. En: http://hum.unne.edu.ar/revistas/geoweb/default.htm 


\section{Economía Keynesiana}

-El sistema capitalista no se autorregula durante las épocas de crisis.

-Es necesaria la intervención del Estado para reactivar la economía, aumentando la demanda de bienes.

-Política de subsidios y reducciones de impuestos: aumento de las compras (demanda)- empresas producen mas (contratan más personal).
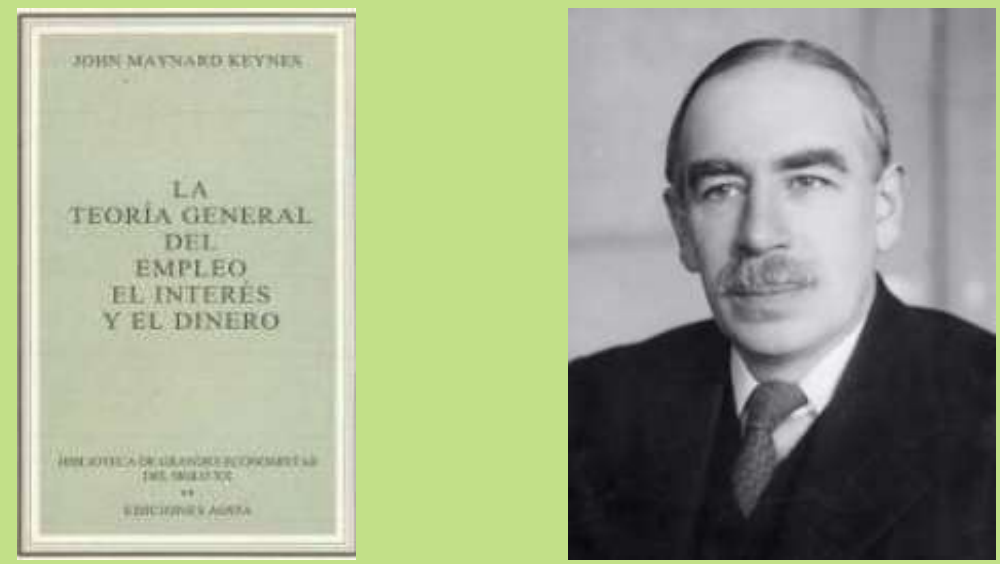

\section{ESTADO DE BIENESTAR}

\section{El Estado}

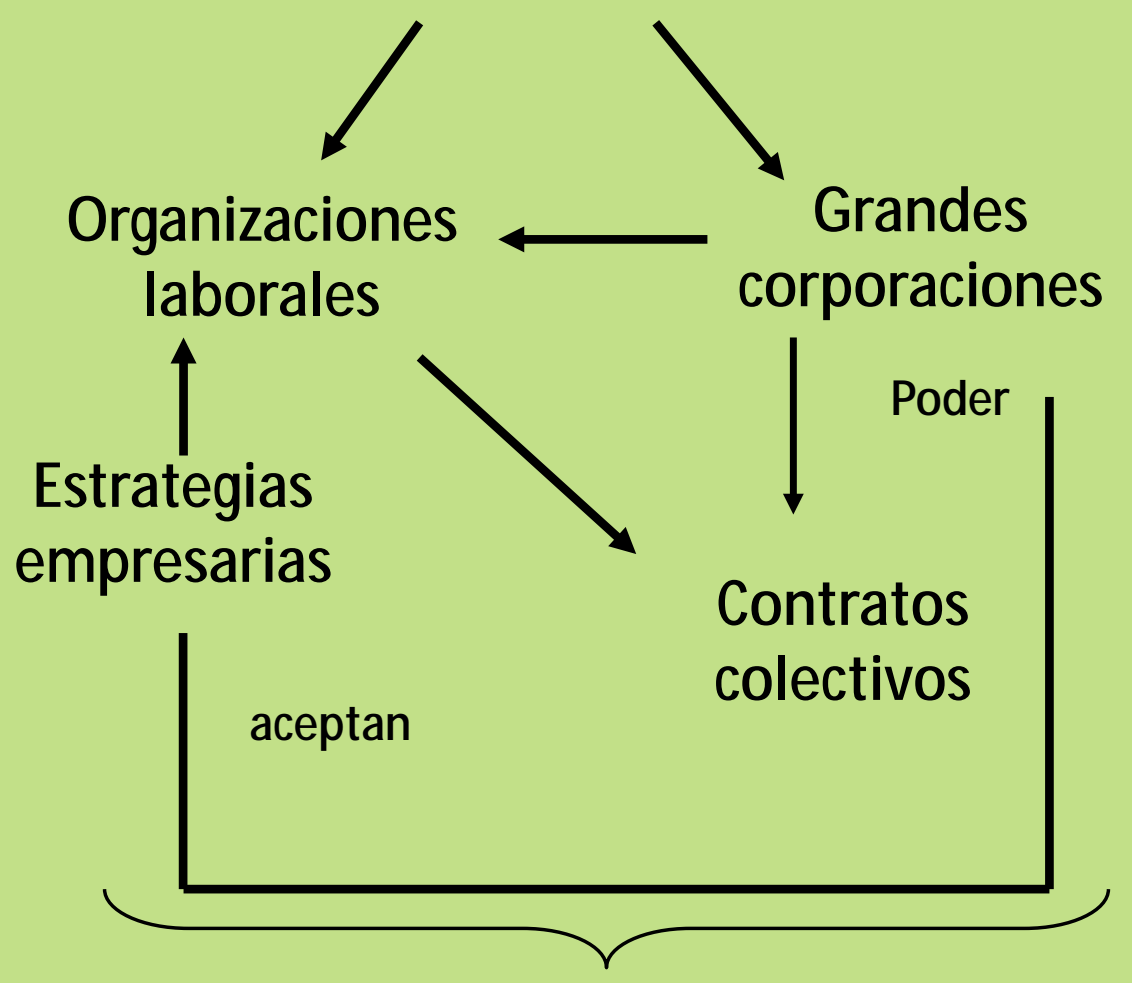

"Estado de Bienestar"

Fuente: Imágenes obtenidas de Tematika.com, S/ f. La Economía online, 2012

Publicado en formato digital: Prof. María del Mar Solís Carnicer, Lic. Silvia Castelán, Prof. Mayra Maggio, Prof. Aníbal M. Mignone y Prof. Alejandra H. Torre Geraldi. El desarrollo industrial en la Argentina. Análisis desde la Historia y la Geografía, Producción en docencia. Revista Geográfica Digital. IGUNNE. Facultad de Humanidades. UNNE. Año 13. № 26. Julio - Diciembre 2016. Resistencia, Chaco. En: http://hum.unne.edu.ar/revistas/geoweb/default.htm 


\section{PERÍODOS HISTÓRICOS}

\begin{tabular}{|l|l|l|}
\hline \multicolumn{1}{|c|}{ Período } & \multicolumn{1}{|c|}{ POĹTICA } & \multicolumn{1}{c|}{ ECONOM ÍA } \\
\hline $1536-1810$ & $\begin{array}{l}\text { Etapa Colonial/Virreinato del Río } \\
\text { de la Plata (1776) }\end{array}$ & Economías Regionales de Subsistencia \\
\hline $1810-1853$ & Revolución e Independencia & Ganadería- Comercio- Actividades artesanales \\
\hline $1853-1880$ & Organización Nacional & Saladeros \\
\hline $1880-1916$ & Régimen Conservador & Economía primaria exportadora \\
\hline $1916-1930$ & Etapa Radical & Economía primaria exportadora \\
\hline $1930-1932$ & Golpe- Uriburu & Crisis económica \\
\hline $1932-1943$ & Etapa Neoconservadora & $\begin{array}{l}\text { Industrialización por Sustitución de } \\
\text { Importaciones (Fase sencilla) }\end{array}$ \\
\hline $1943-1946$ & Golpe. Ramírez y Farrell & $\begin{array}{l}\text { Industrialización por Sustitución de } \\
\text { Importaciones (Fase sencilla) }\end{array}$ \\
\hline $1946-1955$ & Etapa peronista & $\begin{array}{l}\text { Industrialización por Sustitución de } \\
\text { Importaciones (Fase sencilla) }\end{array}$ \\
\hline
\end{tabular}

Publicado en formato digital: Prof. María del Mar Solís Carnicer, Lic. Silvia Castelán, Prof. Mayra Maggio, Prof. Aníbal M. Mignone y Prof. Alejandra H. Torre Geraldi. El desarrollo industrial en la Argentina. Análisis desde la Historia y la Geografía, Producción en docencia. Revista Geográfica Digital. IGUNNE. Facultad de Humanidades. UNNE. Año 13. № 26. Julio - Diciembre 2016. Resistencia, Chaco. En: http://hum.unne.edu.ar/revistas/geoweb/default.htm 


\section{PERIODIZACIÓN}

\begin{tabular}{|l|l|l|}
\hline \multicolumn{1}{|c|}{ Período } & \multicolumn{1}{|c|}{ POĹTICA } & \multicolumn{1}{c|}{ ECONOMÍA } \\
\hline $1955-1958$ & Golpe. Lonardi y Aramburu & \\
\hline $1958-1962$ & Frondizi & ISI Fase Compleja- Desarrollismo \\
\hline 1962 & Golpe. Guido & ISI Fase Compleja \\
\hline $1963-1966$ & Illia & ISI Fase Compleja \\
\hline $1966-1973$ & $\begin{array}{l}\text { Golpe. Onganía- Levingston y } \\
\text { Lanusse }\end{array}$ & ISI Fase Compleja \\
\hline $1973-1976$ & Perón-Isabel Perón & ISI Fase Compleja \\
\hline $1976-1983$ & $\begin{array}{l}\text { Golpe. Videla, Massera, Galtieri, } \\
\text { Bignone }\end{array}$ & $\begin{array}{l}\text { Modelo Rentístico Financiero } \\
\text { Desindustrializacióm }\end{array}$ \\
\hline $1983-1989$ & Alfonsín & Hiperinflación \\
\hline $1989-1999$ & M enem & Convertibilidad \\
\hline $1999-2001$ & De la Rúa & Crisis \\
\hline $2002-2015$ & Duhalde-Kirchner-Fernández & \\
\hline
\end{tabular}

Publicado en formato digital: Prof. María del Mar Solís Carnicer, Lic. Silvia Castelán, Prof. Mayra Maggio, Prof. Aníbal M. Mignone y Prof. Alejandra H. Torre Geraldi. El desarrollo industrial en la Argentina. Análisis desde la Historia y la Geografía, Producción en docencia. Revista Geográfica Digital. IGUNNE. Facultad de Humanidades. UNNE. Año 13. № 26. Julio - Diciembre 2016. Resistencia, Chaco. En: http://hum.unne.edu.ar/revistas/geoweb/default.htm 


\section{Desde fines del siglo XIX hasta 1930}

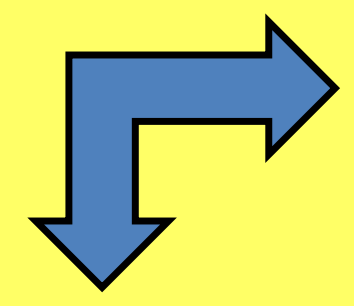

Política conservadora/ Política radical

Empieza a organizarse el movimiento obrero (Anarquistas, Socialistas y Sindicalistas)

Inmigración Masiva - cambios en la sociedad

\section{Conflictos sociales - Papel del Estado}

1910: $10 \%$ de la población trabajaba en la industria

Fuente: Bellini y Korol, 2012; Gerchunoff y Uach, 2000.

\section{Predominan actividades industriales derivadas de la producción agropecuarias con muy pocas innovaciones técnicas}

- Surgen los frigoríficos: procesamiento de carne congelada y enfriada.

- Se expanden las fábricas de bebidas, alimentos, aceite, lácteos, industria azucarera, vitivinícola, taninera.

- Surgen las primeras fábricas textiles y de calzado.

- Primeros emprendimientos metalúrgicos :Tamet y La Cantábrica.

- La Primera Guerra Mundial (1914-1918), reveló la dependencia externa en materia de máquinas y herramientas que arrastraba la industria local. Pero a la vez, posibilitó la llegada de nuevos capitales (EEUU) y la elaboracion de químicos, papel, materiales de construcción, enșamblado de automóviles, petróleo, textiles (algodón).

Publicado en formato digital: Prof. María del Mar Solís Carnicer, Lic. Silvia Castelán, Prof. Mayra Maggio, Prof. Aníbal M. Mignone y Prof. Alejandra H. Torre Geraldi. El desarrollo industrial en la Argentina. Análisis desde la Historia y la Geografía. Producción en docencia. Revista Geográfica Digital. IGUNNE. Facultad de Humanidades. UNNE. Año 13. № 26. Julio - Diciembre 2016. Resistencia, Chaco. En: http://hum.unne.edu.ar/revistas/geoweb/default.htm 


\section{Características de la Etapa Agroexportadora}

\section{Ventajas comparativas}

- Los países tienden a especializarse en la producción y exportación de aquellos bienes que fabrican con un coste relativamente más bajo respecto al resto del mundo, en los que son comparativamente más eficientes que los demás....

- Y tenderán a importar los bienes en los que son más ineficaces y que por tanto producen con unos costes comparativamente más altos que el resto del mundo (Economía y Finanzas Internacionales. S/F.)

Tenemos:

V Noreste de Europa y Noreste de EE. UU.: agricultura intensiva y a una ganadería lechera.

V El este de Europa y el centro-oeste de EE.UU.: cereales.

V Argentina: se dedicaba a la ganadería extensiva. 


\section{Características de la Etapa Agroexportadora}

- En el ingreso al Sistema Mundial, Argentina queda en el área mercantil inglesa como productora de materia primas agropecuarias.

- Según las ventajas comparativas y la estructuración del sistema mundial, los elementos fundamentales fueron:

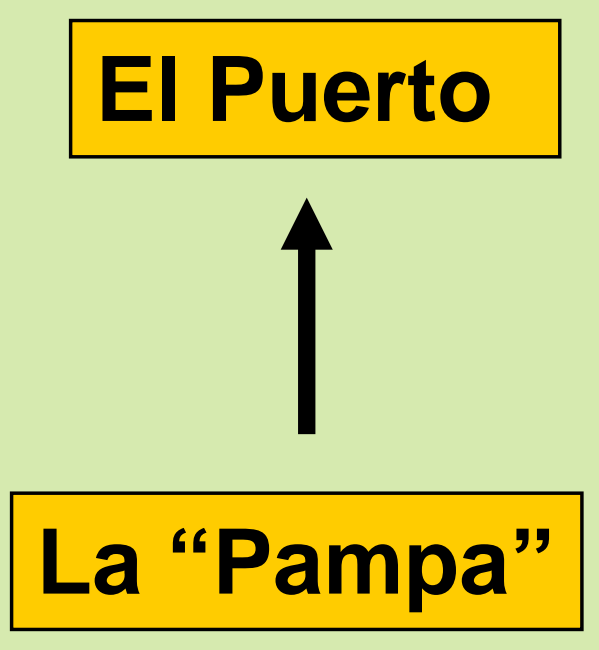

\section{Ferrocarril}

Fuente: Elaboración propia en base a Dozo, 1992: 311- 327

Publicado en formato digital: Prof. María del Mar Solís Carnicer, Lic. Silvia Castelán, Prof. Mayra Maggio, Prof. Aníbal M. Mignone y Prof. Alejandra H. Torre Geraldi. El desarrollo industrial en la Argentina. Análisis desde la Historia y la Geografía, Producción en docencia. Revista Geográfica Digital. IGUNNE. Facultad de Humanidades. UNNE. Año 13. № 26. Julio - Diciembre 2016. Resistencia, Chaco. En: http://hum.unne.edu.ar/revistas/geoweb/default.htm 


\section{Comienza la consolidación del desarrollo} industrial en la región pampeana

\section{Etapa Agroexportadora}

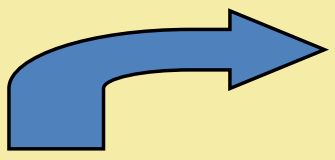

- Surgen barrios obreroindustriales

-El frente ribereño Paraná-Plata

- Ciudad-Puerto de Buenos Aires

- Avellaneda y zonas aledañas

- Berisso-Ensenada (La Plata)

- Campana (destilerías de petróleo)

- Rosario (frigoríficos, textiles, metalúrgicas, molinera)

- Berazategui (vidrio)

- Quilmes (bebidas)

- Se produce la expansión urbana

- Aumento del mercado consumidor dimensiones).

(grandes

- Disponibilidad de mano de obra e infraestructura

- Cercanía a los puertos
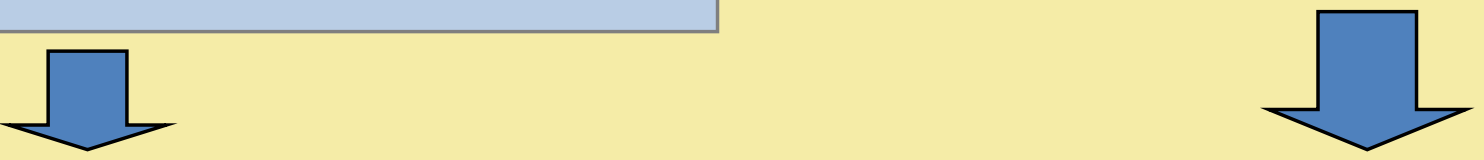

\section{Polo hegemónico del modelo agroexportador y posteriormente del modelo ISI}




\section{Industrialización del Tanino en el NEA}

Entre 1930- 1940:
Chaco: 16 fábricas
Santa Fe: 8
Formosa: 2
Corrientes: 1

Productos:

- Tanino

- Durmientes

- Postes, Vigas.

- Leñas.

- Adoquines

\section{Explotación forestal del quebracho (obrajes)}

Fábricas de elaboración del tanino.

Avance sobre el lomo sudchaqueñosantafesino: sobre la cuña boscosa.

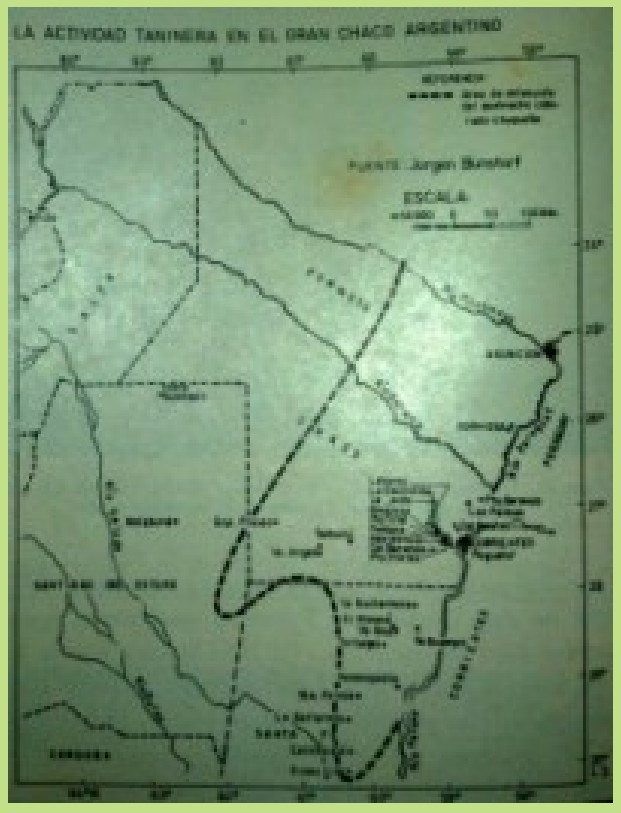

Fuente: Bruniard 1975-1978; Zarrili, 2000. Imagen obtenida de Bruniard, 1975- 1978: 48 . Fig. 46 


\section{Etapa Agroexportadora}

V La Pampa Húmeda:

Actividades Agroind ustriales puntuales: Molinera y lácteos (Buenos Aires Santa Fe y Córdoba). Minero-industrial (cemento Olavarrí).

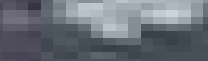 \\ $\checkmark$ NEA}

Cobre auge la in ustría del tanino
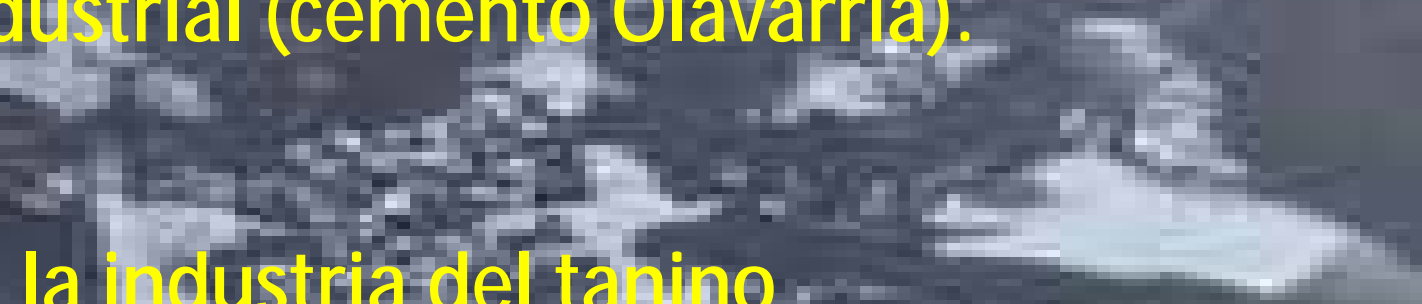

要
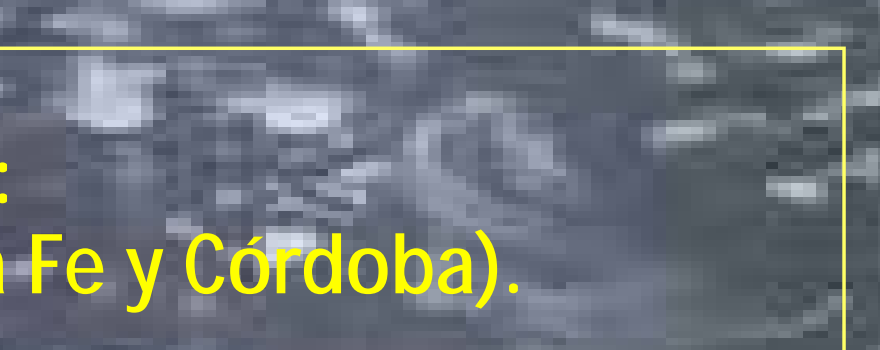
=11

cuvo inolose

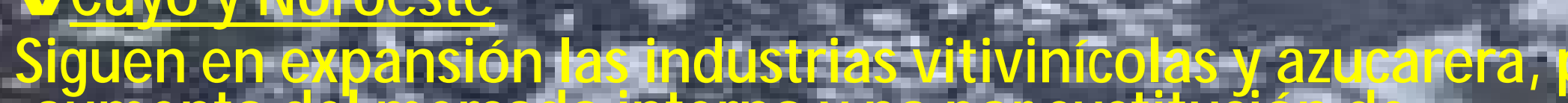
aumento del mercado, interno y no por sustituélon de importaciones, acemás de artesanía ocales-

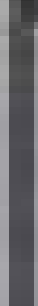

1

$$
\text { portares }
$$
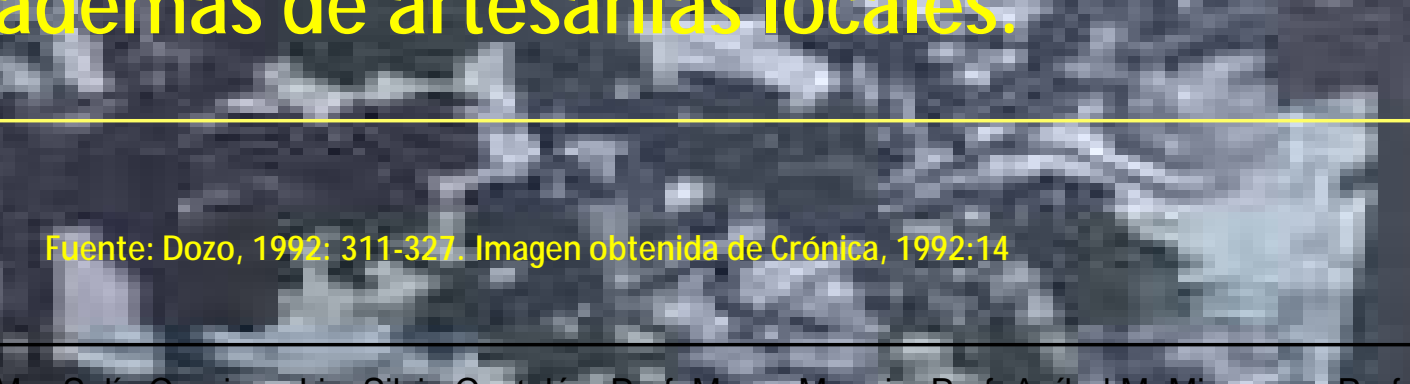

obtenida de Crónica, 1992:14

e Crónica, 1992:14

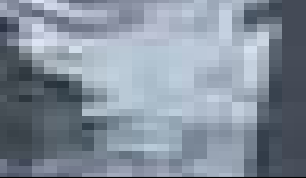




\section{Fin de Etapa Agroexportadora}
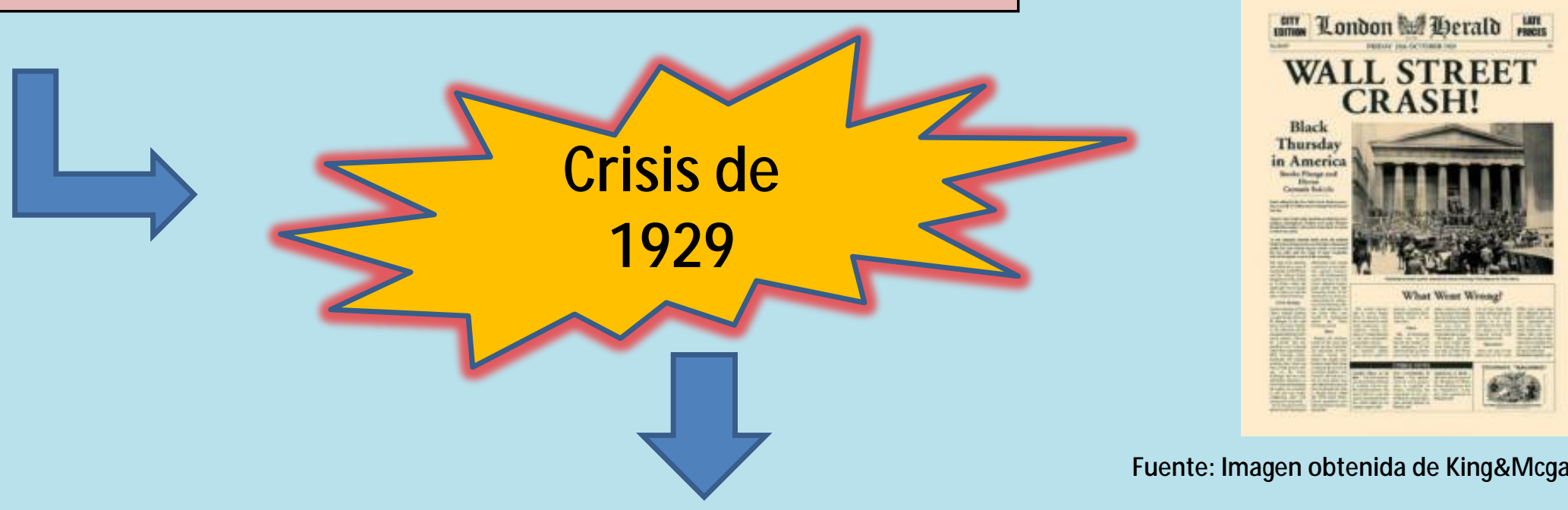

Fuente: Imagen obtenida de King\&M cgaw. S/ f

- Los países comienzan a imponer barreras proteccionistas.

- Dañó al sistema económico argentíno bașado en la producción agropecuaria exportable y modíficó los vínculos con el sistema internacional.

- Esta crisis y posteriormente la Segunda Guerra M undial provocaron el despegue del proyecto industrialista (Dozo, 1992: 315- 316)

Publicado en formato digital: Prof. María del Mar Solís Carnicer, Lic. Silvia Castelán, Prof. Mayra Maggio, Prof. Aníbal M. Mignone y Prof. Alejandra H. Torre Geraldi. El desarrollo industrial en la Argentina. Análisis desde la Historia y la Geografía, Producción en docencia. Revista Geográfica Digital. IGUNNE. Facultad de Humanidades. UNNE. Año 13. № 26. Julio - Diciembre 2016. Resistencia, Chaco. En: http://hum.unne.edu.ar/revistas/geoweb/default.htm 


\section{INDUSTRIALIZACIÓN POR SUSTITUCIÓN DE IM PORTACIONES- FASE SENCILLA (Década de 1930)}
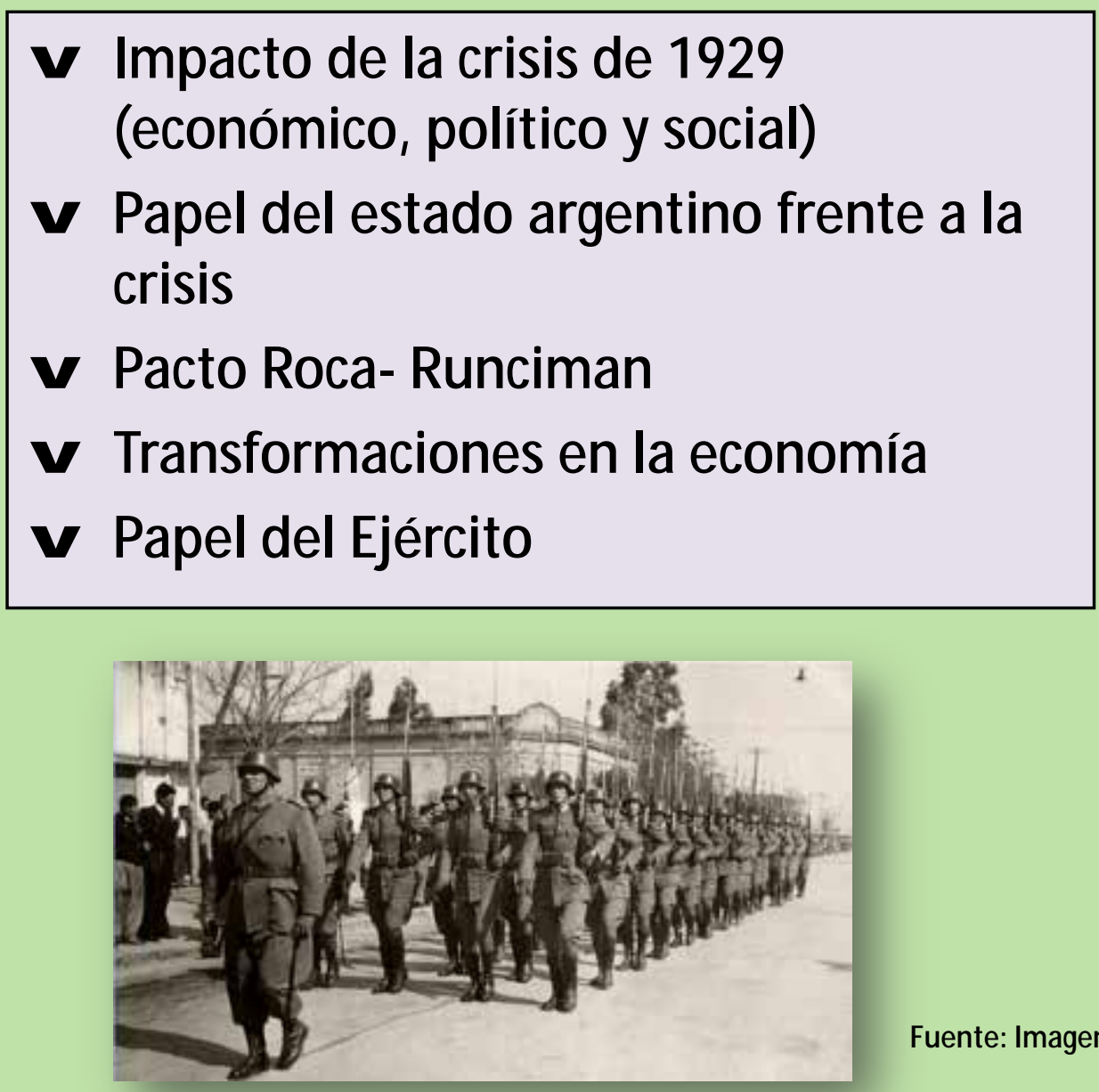

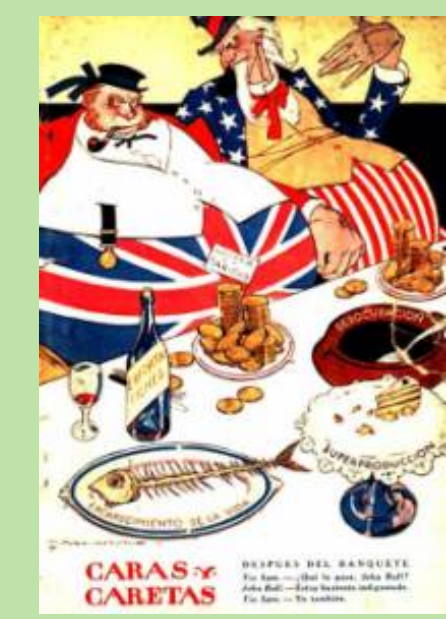

Imagen obtenida de Serqueiros, 2013

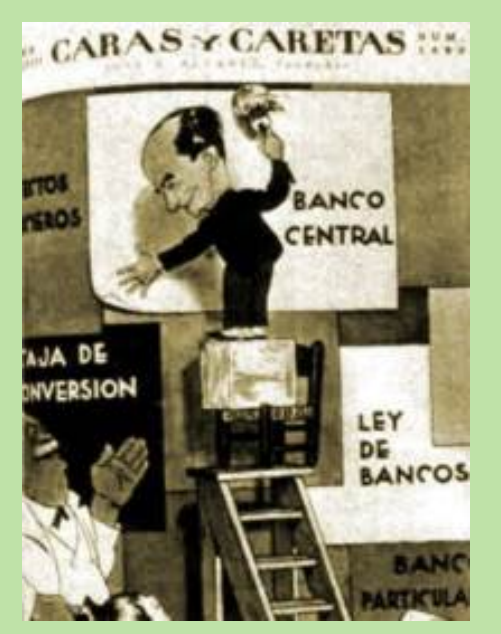

Imagen obtenida de Mágicas ruinas. S/ f

Fuente: Imagen obtenida de Taringa.net. S/f.

Publicado en formato digital: Prof. María del Mar Solís Carnicer, Lic. Silvia Castelán, Prof. Mayra Maggio, Prof. Aníbal M. Mignone y Prof. Alejandra H. Torre Geraldi. El desarrollo industrial en la Argentina. Análisis desde la Historia y la Geografía, Producción en docencia. Revista Geográfica Digital. IGUNNE. Facultad de Humanidades. UNNE. Año 13. № 26. Julio - Diciembre 2016. Resistencia, Chaco. En: http://hum.unne.edu.ar/revistas/geoweb/default.htm 


\section{INDUSTRIALIZACIÓN POR SUSTITUCIÓN DE IM PORTACIONES}

\section{CAUSAS}

ß Disminución de las exportaciones en valor y tonelaje.

B Desvalorización de la moneda.

B Aumento de los derechos aduaneros desde 1931.

B Regulación oficial de las importaciones para ajustarlas al nivel de las venta ß Existencia de un mercado consumidor relativamente importante.

BMano de obra barata.

ßVariedad y existencia de materias primas industriales.

ßPresencia de industrias auxiliares desarrolladas.

ß Desmantelamiento de industrias en EEUU. 


\section{INDUSTRIALIZACIÓN POR SUSTITUCIÓN DE IM PORTACIONES}

\section{CARACTERISTICAS}

v Producción de textiles, alimentos, químicos y mecánicos.

$\checkmark$ Se reduce el peso del déficit comercial con el exterior, ofrecen una salida a la producción agropecuaria y disminuyen la dependencia de las fluctuaciones de los mercados externos.

v Crecimiento de la industria textil se desarrolla con materia prima nacional (lana y algodón).

v Industria Textil alcanzó sus tasas más elevadas de crecimiento durante la Segunda Guerra Mundial.

V Improvisación.

V Emplea equipamiento importado usado y obsoleto.

V Abastecimiento de insumos es irregular, costoso y no siempre de buena calidad.

v Nuevas líneas de producción (capitales extranjeros).

v La ayuda crediticia estatal se dirige a las industrias básicas de la alimentación. 


\section{INDUSTRIALIZACIÓN POR SUSTITUCIÓN DE IM PORTACIONES}

- CONDICIONES LABORALES:

- Situación obrera precaria

- Huelgas eran ilegales

- Carecían de leyes de seguridad social

- No tenían tribunales de trabajo ni reconocimiento de sus derechos

- Había diferencias entre la situación del obrero según el tamaño de las fábricas o empresas y los principios de organización laboral que regían en el sector empresarial

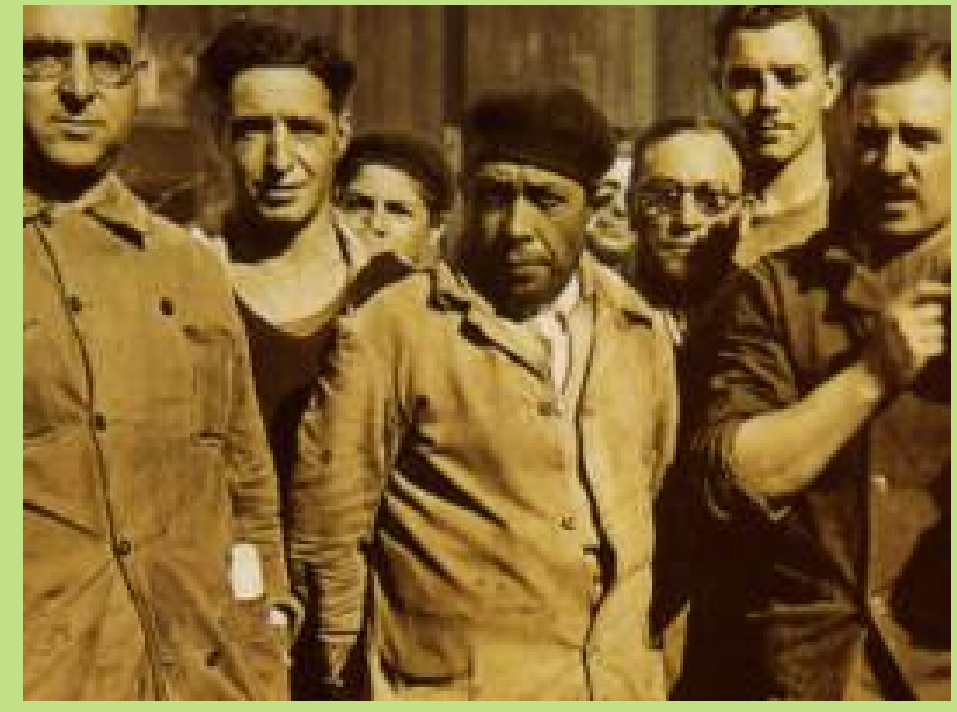

Fuente: Imagen obtenida de El historiador. S/ f. 


\section{La industria durante el peronismo (1946-1955)}

- Los recursos acumulados durante la Segunda Guerra mundial posibilitaron la puesta en marcha de estrategias para fomentar la expansión del mercado interno y la industrialización.

$\bullet$

\section{ROL DEL ESTADO}

- El Estado adquiere un rol activo, de promotor de la actividad.

- Algunas medidas políticas previas como la Creación del Banco de Crédito Industrial, de la Secretaria de Industria y Comercio y el primer régimen de promoción industrial (decreto 14.630 de 1944) se profundizaron.

- Se crea DINIE (Dirección Nacional de Industrias del Estado) en 1947. Estado empresario.

- Primer Plan Quinquenal (1947) fomentó la creación de nuevas industrias (acero, laminados, productos químicos) a la vez que protegió las existentes que consideraba prioritarias (textil algodonera y metalúrgica).

- Se aprueba el Plan Siderúrgico y se crea SOMISA para impulsar la producción de acero en el país.
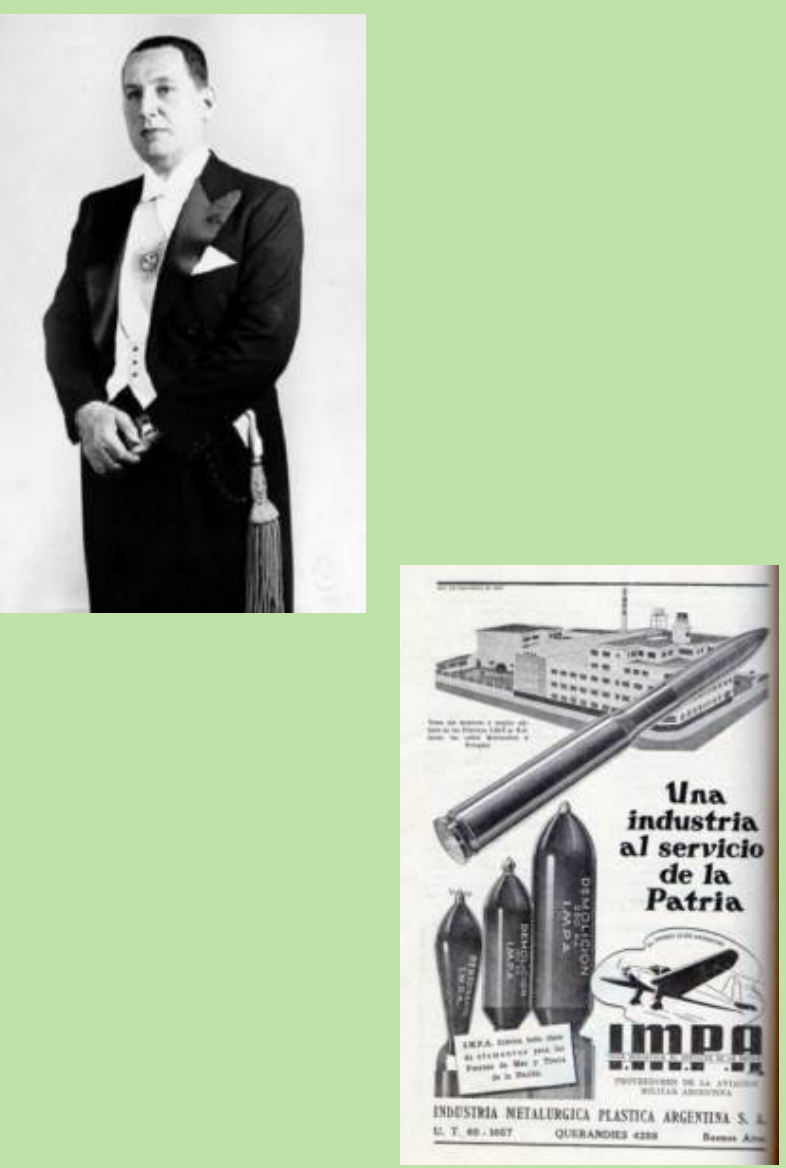

Fuente: Imágenes obtenidas de Wikipedia. S/f; Taringa.net. S/ f.

Publicado en formato digital: Prof. María del Mar Solís Carnicer, Lic. Silvia Castelán, Prof. Mayra Maggio, Prof. Aníbal M. Mignone y Prof. Alejandra H. Torre Geraldi. El desarrollo industrial en la Argentina. Análisis desde la Historia y la Geografía. Producción en docencia. Revista Geográfica Digital. IGUNNE. Facultad de Humanidades. UNNE. Año 13. № 26. Julio - Diciembre 2016. Resistencia, Chaco. En: http://hum.unne.edu.ar/revistas/geoweb/default.htm 


\section{La industria durante el peronismo (1946-1955)}

Algunas limitaciones:
- El país siguió careciendo de industrias
básicas que le permitiesen
autoabastecerse de insumos.
- Las divisas disponibles para adquirir
equipamiento industrial dependían del
sector agrario.

- Durante esta etapa, un importante sector de la población se incorporó a la actividad industrial.

- Se amplia la redistribución de los ingresos y aumenta el consumo.

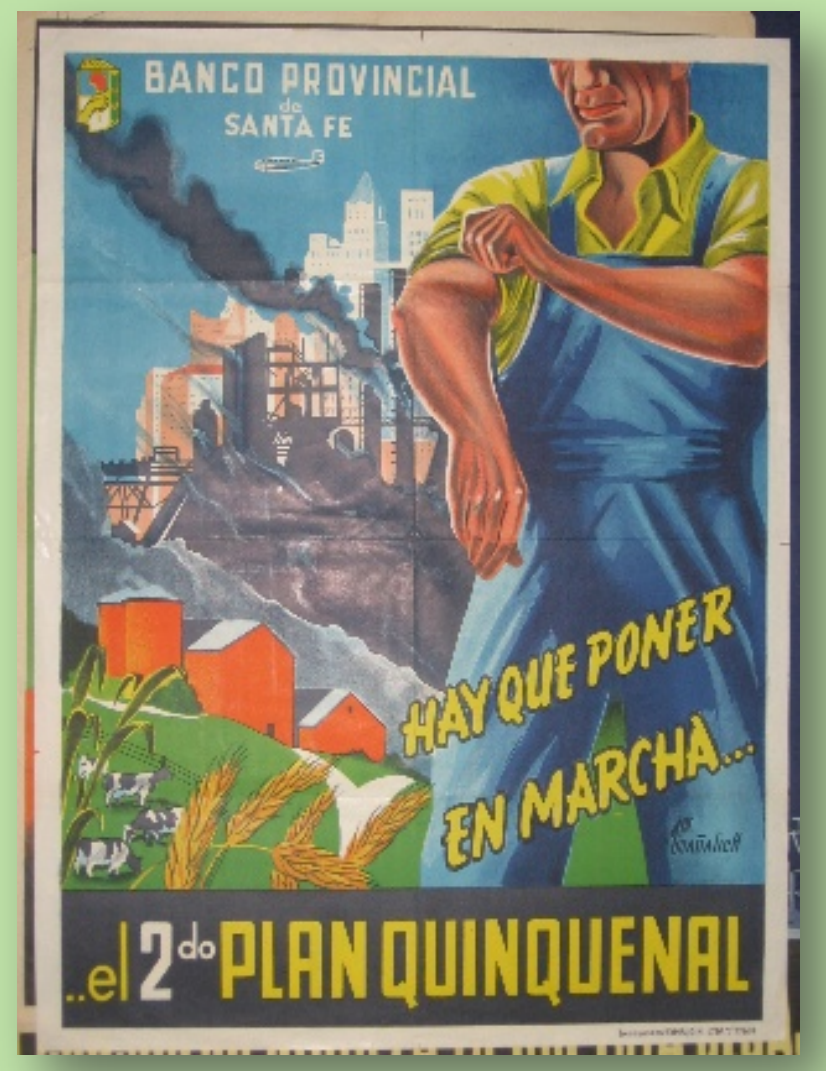

Fuente: Imagen obtenida de Navarro, 2013.

Publicado en formato digital: Prof. María del Mar Solís Carnicer, Lic. Silvia Castelán, Prof. Mayra Maggio, Prof. Aníbal M. Mignone y Prof. Alejandra H. Torre Geraldi. El desarrollo industrial en la Argentina. Análisis desde la Historia y la Geografía, Producción en docencia. Revista Geográfica Digital. IGUNNE. Facultad de Humanidades. UNNE. Año 13. № 26. Julio - Diciembre 2016. Resistencia, Chaco. En: http://hum.unne.edu.ar/revistas/geoweb/default.htm 
- A partir de la década de 1930, se proyecta el sector industrial con los cultivos industriales hacia otras regiones fuera de la Pampa Húmeda.

\section{Tenemos:}

ÿ Algodón en Chaco.

$\ddot{y}$ Té, tung y yerba mate en Misiones y Corrientes.

ÿ Tabaco y caña de azúcar en el NOA y el NEA.

$\ddot{y}$ Vid- Frutas - Olivo - en Cuyo.

ÿ Lanera en Patagonia. 


\section{INDUSTRIALIZACION POR SUSTITUCIÓN DE IM PORTACIONES}

- El objetivo era el autoabastecimiento de alimentos y productos industriales.

- Predominio de actividades de producción y servicios en gran escala.

- Grandes aglomerados territoriales de población y producción y sistemas decisionales y organizacionales verticalizados, jerarquizados y centralizados.

- Se produce la concentración de la producción, la población y la infraestructura en grandes ciudades industriales.

- La promoción industrial se practica a través de mecanismos como la alta protección arancelaria externa, buscando favorecer las industrias de bienes finales intermedios.
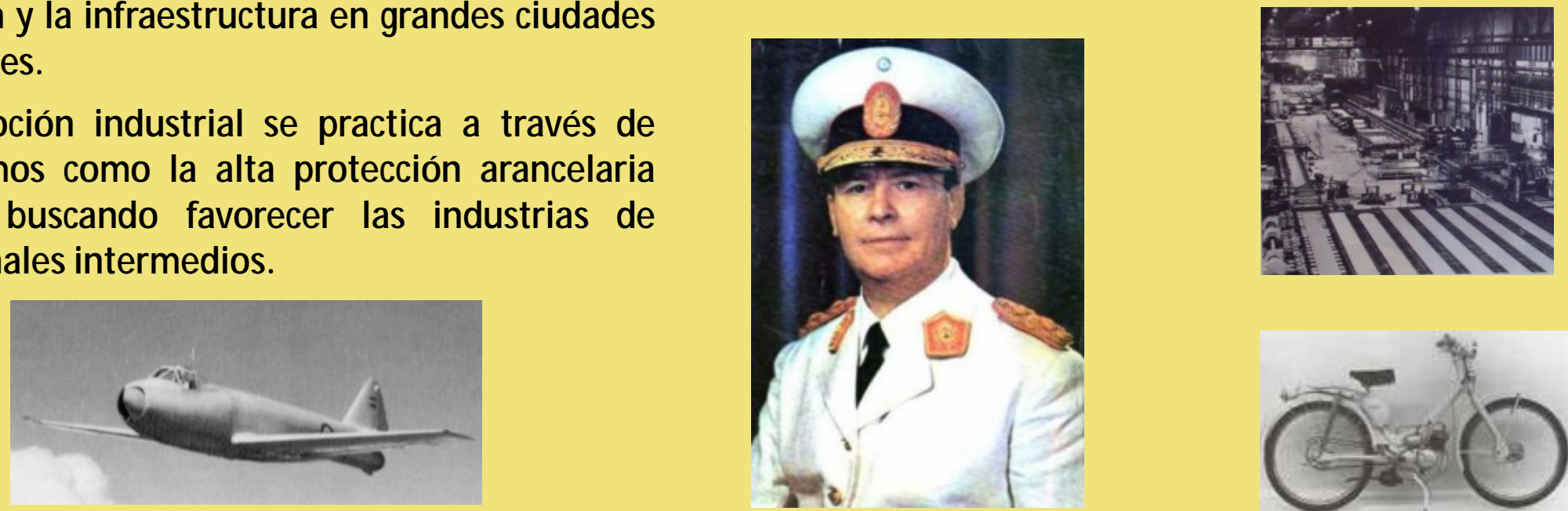

Fuente: Imágenes obtenidas de Wikipedia.org, S/ f.

Publicado en formato digital: Prof. María del Mar Solís Carnicer, Lic. Silvia Castelán, Prof. Mayra Maggio, Prof. Aníbal M. Mignone y Prof. Alejandra H. Torre Geraldi. El desarrollo industrial en la Argentina. Análisis desde la Historia y la Geografía. Producción en docencia. Revista Geográfica Digital. IGUNNE. Facultad de Humanidades. UNNE. Año 13. № 26. Julio - Diciembre 2016. Resistencia, Chaco. En: http://hum.unne.edu.ar/revistas/geoweb/default.htm 


\section{Fines de 1950 y década de 1960}

- Desarrollismo: postura favorable a la industrialización y el impulso de las industrias básicas que permitiría superar los limites estructurales impuestos al crecimiento del país. Comienza la Segunda fase de la ISI.

- Se aplican políticas de estimulo a la inversión extranjera para el desarrollo de industrias básicas:

- Ley de inversiones extranjeras

- Ley de Promoción Industrial. Además se tomaron créditos con el extranjero.

- Se crea el INTA, INTI, CONICET Y CONADE, para el desarrollo científico y asistencia a la industria.

- Las inversiones posibilitaron el desarrollo de la industria automotriz, explotación de petróleo, siderurgia y petroquímica.

- Se estimula la realización de grandes obras de infraestructura: central hidroeléctrica El Chocón, central nuclear Atucha.

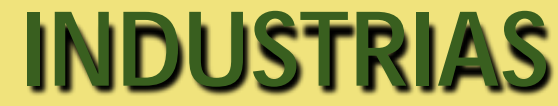

Fuente: Schvarzer, 1996; Belini y Korol, 2012.
Eran de capital-intensivas, requerían el dominio de tecnología de producción compleja y elaboraban productos con mayor grado de sofisticación. 


\section{Fines de 1950 y década de 1960}

- La industrialización de esta etapa incidió en la formación de mano de obra local calificada, en la mejora de técnicas administrativas, el control de calidad.

- Sin embargo el autoritarismo, los conflictos sociales y la inestabilidad política impidió un crecimiento sostenido.

- Las políticas ensayadas se caracterizaron por cambios bruscos en los incentivos y las orientaciones dadas a la actividad industrial, que no pudo superar sus limitaciones estructurales:

a) El sector industrial continuó dependiendo del mercado interno.

b) La puja distributiva, la inflación, el atraso cambiario y la apertura económica condicionaron el desempeño del sector.

- El proceso de industrialización continuó hasta 1973.
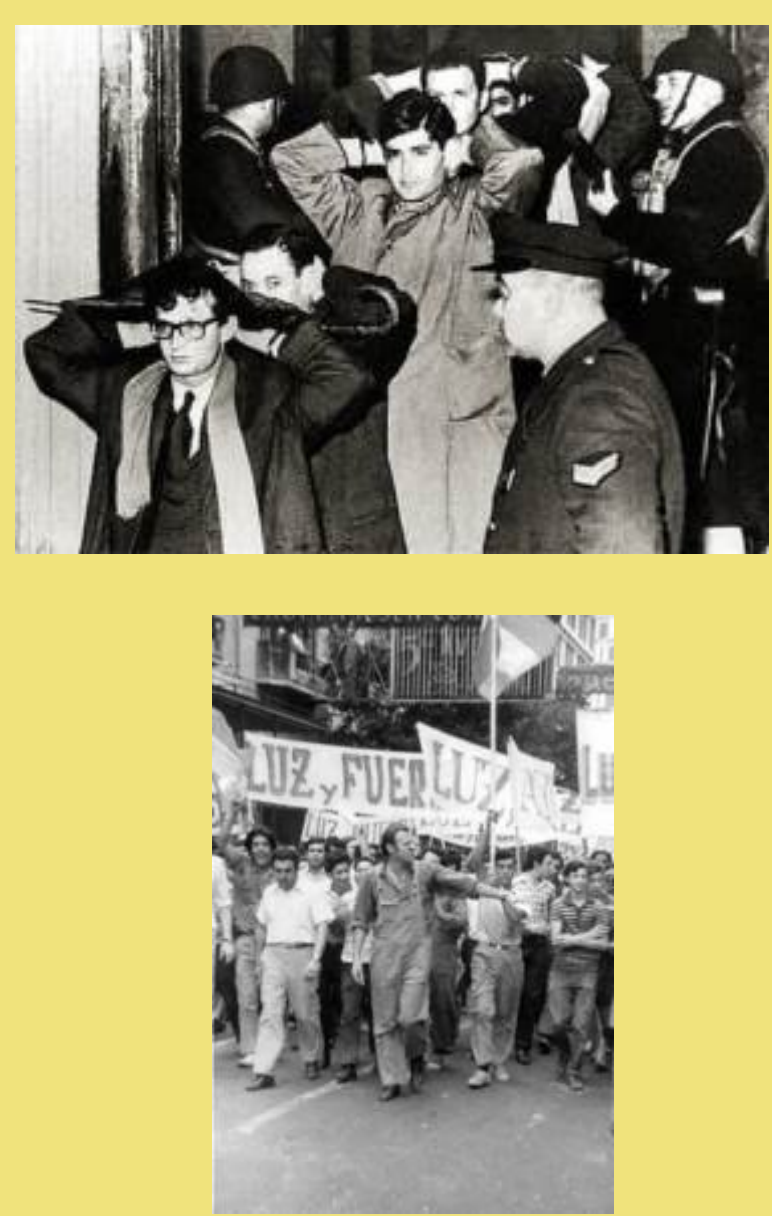

Fuente: Imágenes obtenidas de Aliaga, S/f. El Ortiba, S/ f.

Publicado en formato digital: Prof. María del Mar Solís Carnicer, Lic. Silvia Castelán, Prof. Mayra Maggio, Prof. Aníbal M. Mignone y Prof. Alejandra H. Torre Geraldi. El desarrollo industrial en la Argentina. Análisis desde la Historia y la Geografía. Producción en docencia. Revista Geográfica Digital. IGUNNE. Facultad de Humanidades. UNNE. Año 13. № 26. Julio - Diciembre 2016. Resistencia, Chaco. En: http://hum.unne.edu.ar/revistas/geoweb/default.htm 


\section{INDUSTRIALIZACIÓN POR SUSTITUCIÓN DE IM PORTACIONES-SEGUNDA FASE}

- Se intensifica el desarrollo de la industria de base, con radicación de capital y tecnología extranjera.

- Se desarrolla la industria automotriz y petroquímica (Petroquímicas: General Mosconi y Bahía Blanca).

- Industria de aluminio y papel prensa.

- Disminución de las pequeñas industrias y aparición de las empresas transnacionales.

- Modernización de la infraestructura energética (1960-1980).
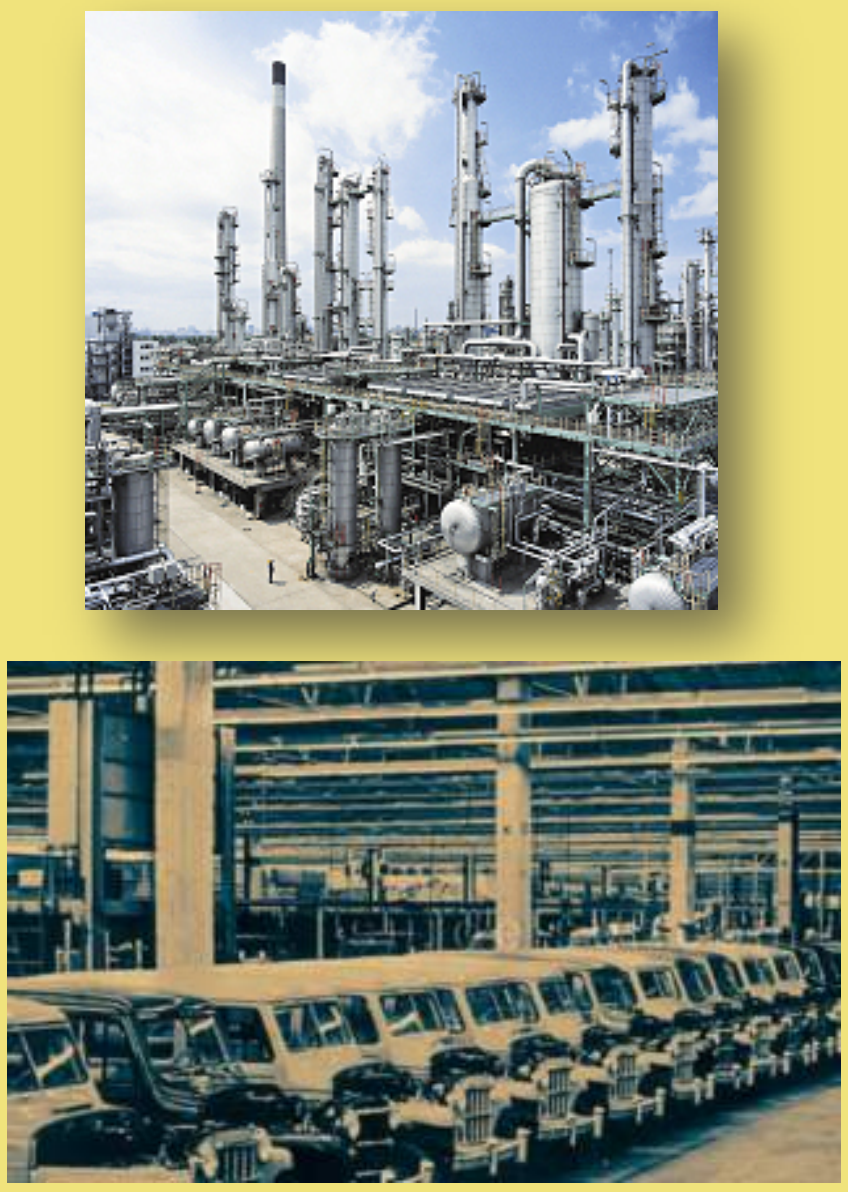

Fuentes: Imágenes obtenidas de Wikipedia.org, S/f; El Sur del sur. S/f.

Publicado en formato digital: Prof. María del Mar Solís Carnicer, Lic. Silvia Castelán, Prof. Mayra Maggio, Prof. Aníbal M. Mignone y Prof. Alejandra H. Torre Geraldi. El desarrollo industrial en la Argentina. Análisis desde la Historia y la Geografía, Producción en docencia. Revista Geográfica Digital. IGUNNE. Facultad de Humanidades. UNNE. Año 13. № 26. Julio - Diciembre 2016. Resistencia, Chaco. En: http://hum.unne.edu.ar/revistas/geoweb/default.htm 


\section{Concentración industrial}

Esta área es hoy:

- El núcleo industrial más antiguo,

- Sectorialmente diferenciado

- Territorialmente más extenso.

Crecimiento de los dos principales polos de industrialización en los '60:

- Capital y Gran Buenos Aires (hacia el norte)

- El núcleo conformado en Córdoba- Santa Fe por los departamentos de San Justo Castellanos (hacia el sur).

- Se conforma un gran área industrializada que abarca Capital Federal y GBA, y se extiende hacia norte, comprendiendo el suroeste de Santa Fe y el sur-este de la provincia de Córdoba.

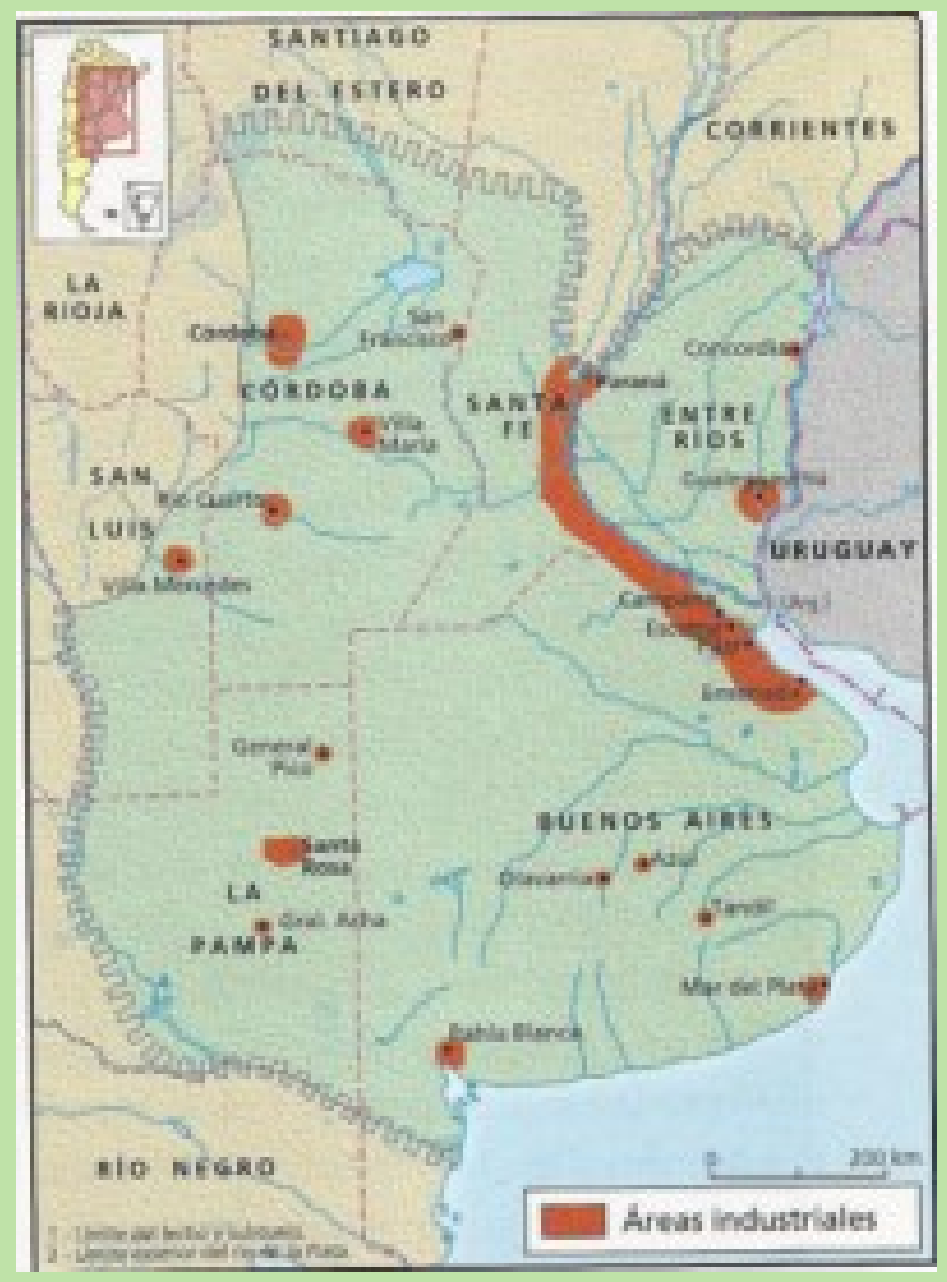

Fuente: Donato, 2007. Imagen obtenida de Echevrría y Capuz, 2000: 245. 


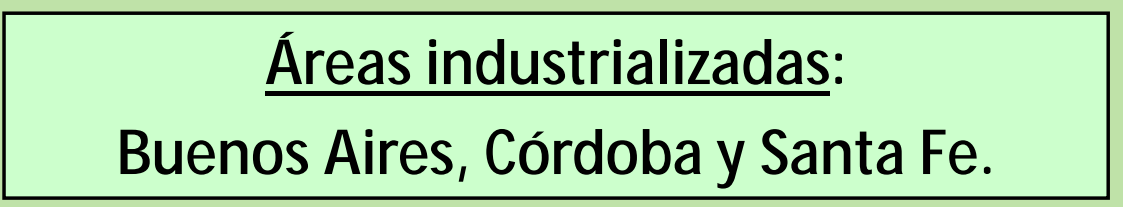

\section{Década de 1960}

\begin{tabular}{|c|}
\hline Áreas de base agroindustrial: \\
NEA: Corrientes, Chaco, Misiones \\
Cuyo: Mendoza, San Juan \\
NOA:, Jujuy, Salta, Tucumán. \\
Otros pcias: Entre Ríos, Río Negro.
\end{tabular}

Áreas sin desarrollo industrial
Significativo:
NOA: Catamarca, La Rioja, Santiago del
Estero.
Patagonia: Neuquén, Chubut, Santa
Cruz, Tierra del Fuego.
Otras pcias: La Pampa, San Luis,
Formosa.

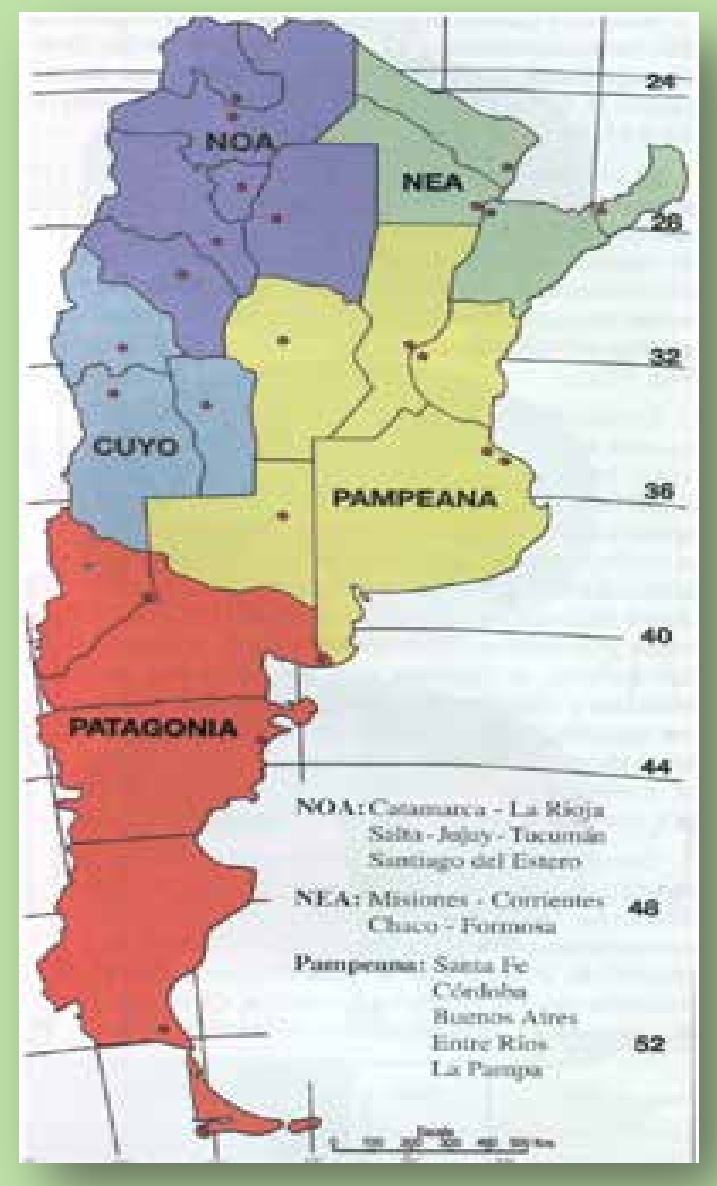

Fuente: Manzanal y Rofman, 1989:46. Imagen obtenida de regionesdeargentina9.blogspot, S/ f. 


\section{Décadas de 1970/ 1980/ 1990}

Bruscos cambios en la orientación del mercado mundial afectaron la
economía de Argentina

\begin{tabular}{|l|l|} 
1) Aumento de los precios de los \\
productos primarios derivó en una \\
especie de retorno a la Argentina \\
agroexportadora y se abandonaron \\
las políticas industrialistas.
\end{tabular}
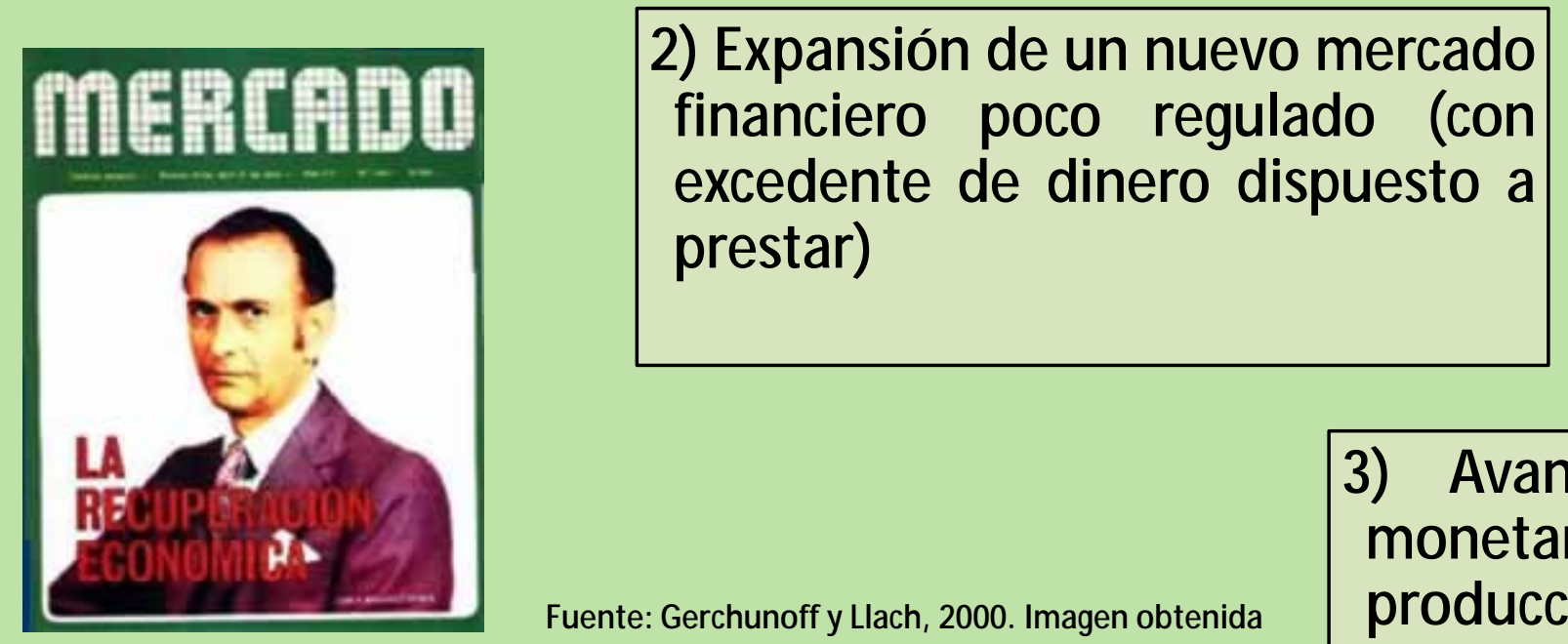

Fuente: Gerchunoff y Llach, 2000. Imagen obtenida de Todo Argentina, $\mathbf{S}$ f.

\begin{tabular}{l}
$\begin{array}{l}\text { 3) Avance de la ideología } \\
\text { monetarista } \\
\text { producción) }\end{array}$ \\
\hline
\end{tabular}


- Etapa de grandes cambios que transformaron la estructura productiva y marcaron un quiebre en el modelo de desarrollo.

- El sector manufacturero dejó de ser el motor impulsor del crecimiento debido a la apertura económica, el atraso cambiario, la destrucción del tejido industrial, la pérdida de capacidades tecnológicas, el impulso de la especulación financiera, la fuga de capitales, las medidas a corto plazo.

- El incremento de los costos financieros, el recrudecimiento de la competencia extranjera, la reducción de aranceles afectó la rentabilidad de las empresas industriales, sobre todo en las ramas textiles, maderas, metales básicos.

- Industrias: reducen costos, contraen estructuras, se achican, desaparecen, se eliminan las áreas de estudios y proyectos.

-Algunas empresas (grandes) sobrevivieron y se convirtieron en agentes financieros.

- Compra y venta de empresas como un juego financiero.

- Apertura indiscriminada a productos importados.

- Paralelamente se establecen subsidios de promoción regional (vinculado al conflicto social).

- Fuerte crecimiento de la deuda externa.

- Represión social (física y del empleo).

\section{Dictadura (1976-1983)}
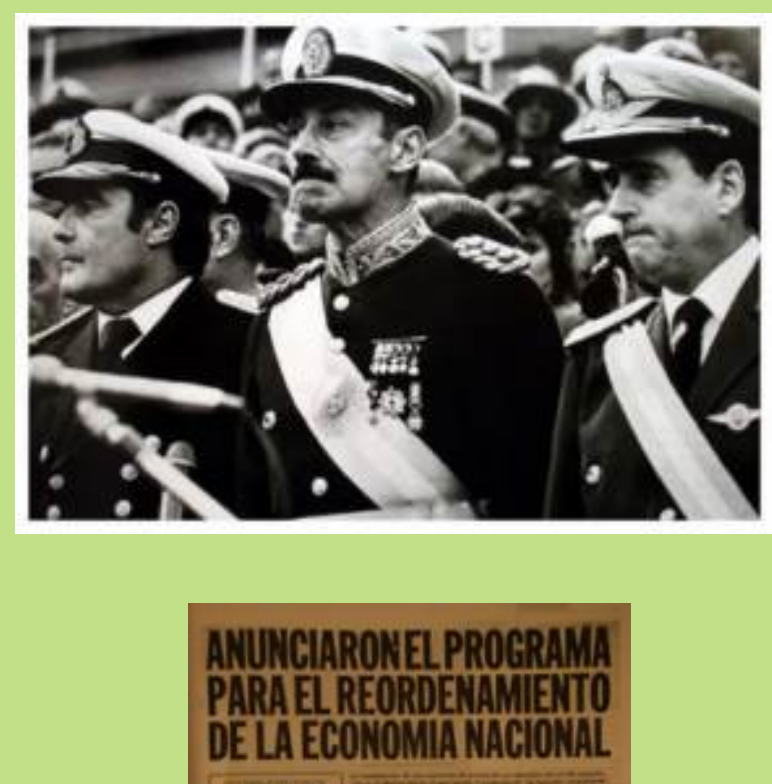

Clarin $^{8}$

Disponen Io liberación de precios

El gobierno establecerá los salarios

Aumentan los combustibles y el gas

Fue modificado el régimen impositivo

Anula lo Lev de lnversiones Externas

Fuente: Imágenes obtenidas de Todo Argentina, S/f.; ACIJ, 2012.

Publicado en formato digital: Prof. María del Mar Solís Carnicer, Lic. Silvia Castelán, Prof. Mayra Maggio, Prof. Aníbal M. Mignone y Prof. Alejandra H. Torre Geraldi. El desarrollo industrial en la Argentina. Análisis desde la Historia y la Geografía, Producción en docencia. Revista Geográfica Digital. IGUNNE. Facultad de Humanidades. UNNE. Año 13. № 26. Julio - Diciembre 2016. Resistencia, Chaco. En: http://hum.unne.edu.ar/revistas/geoweb/default.htm 


\section{Período 1983-2001}

$\ddot{y} \quad$ La recuperación de la democracia puso en agenda la recuperación de los derechos políticos y la reconstrucción de las libertades públicas, por lo que los problemas de la economía quedaron en segundo plano.

$\ddot{y}$ El retroceso de la industria de tecnología compleja, la transnacionalización y la desarticulación del sector manufacturero son ejes del proceso de desindustrialización que se consolida en la década de 1990.

ÿ Dos problemas claves: Deuda externa e inflación.

ÿ Hacia 1990 inician las privatizaciones de las empresas públicas. Rápido proceso de desindustrialización.

$\ddot{y} \quad$ Fuerte discurso antiindustrialista (culpable de todos los males argentinos-mala calidad).

$\ddot{y} \quad$ Crecimiento del sector de servicios.
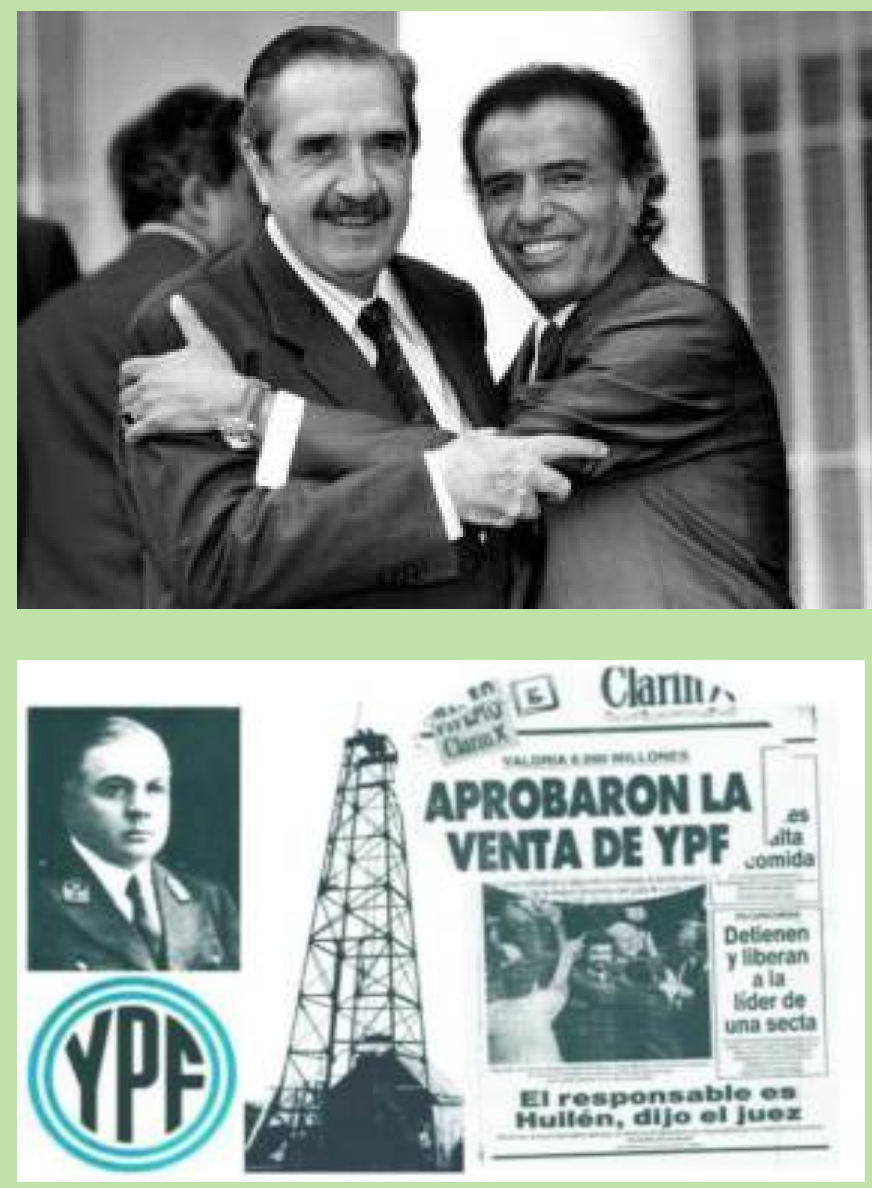

Fuente: Imágenes obtenidas de Las imágenes retro, 2011; Hola Palmira, 2016.

Publicado en formato digital: Prof. María del Mar Solís Carnicer, Lic. Silvia Castelán, Prof. Mayra Maggio, Prof. Aníbal M. Mignone y Prof. Alejandra H. Torre Geraldi. El desarrollo industrial en la Argentina. Análisis desde la Historia y la Geografía, Producción en docencia. Revista Geográfica Digital. IGUNNE. Facultad de Humanidades. UNNE. Año 13. № 26. Julio - Diciembre 2016. Resistencia, Chaco. En: http://hum.unne.edu.ar/revistas/geoweb/default.htm 


\section{Los regímenes de promoción industrial}

- En la década de 1970 y 1980:

- El régimen nace con la Ley $21.608 / 77$, cuya autoridad de aplicación era la Secretaria de Industria.

- El régimen se aplica en las provincias de La Rioja, San Luis, Catamarca y San Juan.

- El reglamento de Área Aduanera Especial derivado de la Ley 19.640/72 permite la aplicación en el Territorio Nacional de Tierra del Fuego.

- Los regímenes de promoción se basaron en:

- Exención de aranceles,

- Beneficios tributarios para la industria promovida y para los inversionistas,

- Beneficios adicionales para la exportación y restricciones temporarias para las importaciones de bienes competitivos.

Fuente: Schvarzer, 1987.

Publicado en formato digital: Prof. María del Mar Solís Carnicer, Lic. Silvia Castelán, Prof. Mayra Maggio, Prof. Aníbal M. Mignone y Prof. Alejandra H. Torre Geraldi. El desarrollo industrial en la Argentina. Análisis desde la Historia y la Geografía, Producción en docencia. Revista Geográfica Digital. IGUNNE. Facultad de Humanidades. UNNE. Año 13. № 26. Julio - Diciembre 2016. Resistencia, Chaco. En: http://hum.unne.edu.ar/revistas/geoweb/default.htm 


\section{Etapa de Reestructuración Económica- Flexibilización - Posfordista}

$\ddot{y}$ Mediados de los '70: crisis financiera- recesión económica 1973: Crisis del petróleo.

$\ddot{y}$ Los países acreedores comienzan a cobrar créditos (deuda externa).

ÿ Declinan los viejos espacios industriales.

$\ddot{y}$ Nuevas áreas de producción: Se preferencias regiones: frontera Méjico- Estados Unidos, países asiáticos.

$\ddot{y}$ Inversiones extranjeras son altamente selectivas: desde países centrales a países centrales o pequeño número de países periféricos (con ventajas competitivas). 


\section{Nueva División Internacional del Trabajo}

\begin{abstract}
, Reestructuración éconómica.

industrial

Pasaje de un modelo fordista clásico a un modelo de acumulación flexible (Harvey) o postfordista.

Se prefiere la inversión especulativa a la productiva: "valorización financiera del capital"

Internacionalización del capital (empresas trasnacionales y corporaciones multinacionales).
\end{abstract}

Reestructuración productiva permite la segmentación del proceso productivo.

Rentabilidad máxima del capital (sitios de producción).
Seleccionados por sus ventajas competitivas en cuanto a:

Existencia de mano de obra medianamente calificada y de bajo costo. Legislaciones laborales y de beneficios sociales altamente flexibles para la empresa.

Organización sindical poco estructurada 0 débil.

La movilidad del capital, de la materia prima semi-elaborada y de la tecnología.

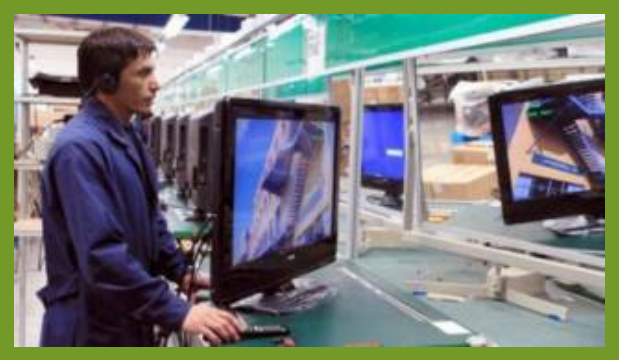

Fuente: Meichtry, 1999. Imagen obtenida de Dávila, 2011. 


\section{Ajuste y Flexibilización Laboral}

- Desde mediados de la década de los 70 , se produce una apertura indiscriminada de la economía, que obró negativamente en la pequeña y mediana industria.

- Disminuyeron las barreras aduaneras y aumentaron los productos importados. El objetivo era controlar la inflación y aumentar la eficiencia de la industria nacional a través de la competencia.

- Pequeñas industrias que recibían el proteccionismo estatal se vieron obligadas a cerrar.

- Aumento tamaño medio de establecimientos

- Disminuyen:

- Peso de los insumos en el valor bruto de producción

- Peso de los salarios en el valor agregado

\begin{tabular}{|l|l|}
\hline Período & $\begin{array}{l}\text { Asalariados. Sector } \\
\text { manufacturero }\end{array}$ \\
\hline $1963-73$ & 200.000 \\
\hline $1973-84$ & 30.000 \\
\hline
\end{tabular}

Influyen:

- Estancamiento de la producción y disminuición de los niveles de inversión.

- "Disciplinamiento" social forzado por el régimen militar.

- Incorporación de tecnologías (ahorro mano de obra).

- Aumento en la intensidad de los procesos de trabajo. 


\section{Ajuste y Flexibilización Laboral}

* Plan de Convertibilidad de 1991.
* Las exportaciones industriales permiten el
crecimiento de algunos sectores (agroindustrias).
* Los agroquímicos, aceites vegetales y
subproductos oleaginosos son los rúbros más
dinamicos.
* Los sectores de pequeñas y medianas empresas
(PyM ES), como los textiles y metalmecánicos
(excepto automotores) son afectados por la
importación de productos.
* Se ven afectadas las pequeñas y medianas
industrias que concentran el mayor número de
empleados (66\% en 1994).
* La industrias sufre una recesión en dos
oportunidades:
- Efecto Tequila (1995)
- Crisis en Rusia (1997) y la devaluación de Brasil
(1999).
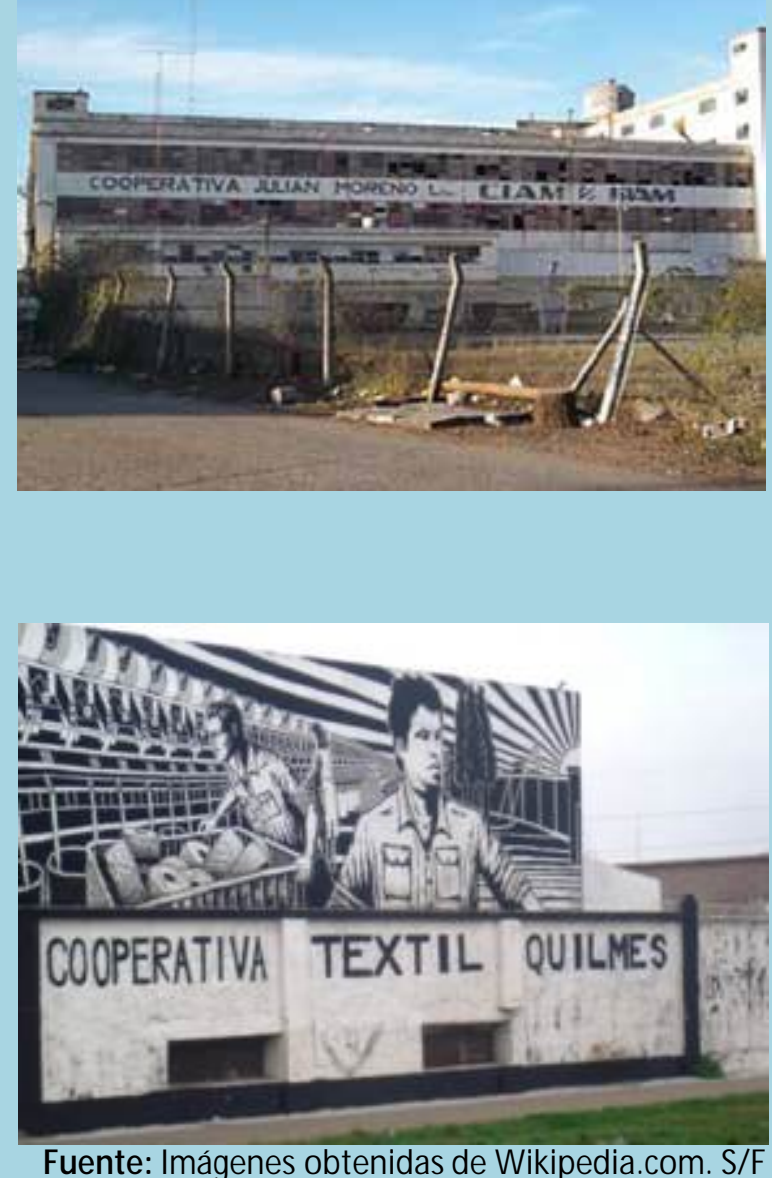
Wikipedia.com. S/F. ANRed, 2009.

Publicado en formato digital: Prof. María del Mar Solís Carnicer, Lic. Silvia Castelán, Prof. Mayra Maggio, Prof. Aníbal M. Mignone y Prof. Alejandra H. Torre Geraldi. El desarrollo industrial en la Argentina. Análisis desde la Historia y la Geografía, Producción en docencia. Revista Geográfica Digital. IGUNNE. Facultad de Humanidades. UNNE. Año 13. № 26. Julio - Diciembre 2016. Resistencia, Chaco. En: http://hum.unne.edu.ar/revistas/geoweb/default.htm 


\section{Desindustrialización relativa}

- Nuevas plantas fuera del área tradicional industrial.

- Relocalización de plantas existentes.

- Regiones del interior del país ganaron participación relativa en la producción de bienes de consumo durable e intermedios por:

- Localización o relocalización de plantas

- El traslado de ciertos procesos industriales (sin abarcar el producto completo) en actividades de bienes de capital y de bienes de consumo no durables.

- No logran sistemas industriales integrados y no logran alterar el patrón histórico de descentralización y concentración geográfica.

Fuente: Manzanal y Rofman 1989.

Industrialización neta: GBA, Córdoba y Santa Fe.

Nuevo desarrollo industrial sobre base de grandes proyectos: Buenos Aires y parcialmente Chubut y M isiones.

Industrialización a partir de regímenes promocionales.

Agroindustriales tradicionales: Corrientes, Chaco, Entre Ríos, Jujuy, Mendoza, Río Negro, Salta, San Juan y Tucumán.

Sin desarrollo industrial: Formosa, La Pampa, Santa Cruz y Santiago del Estero. 


\section{Departamentos industriales 1963- 1994}
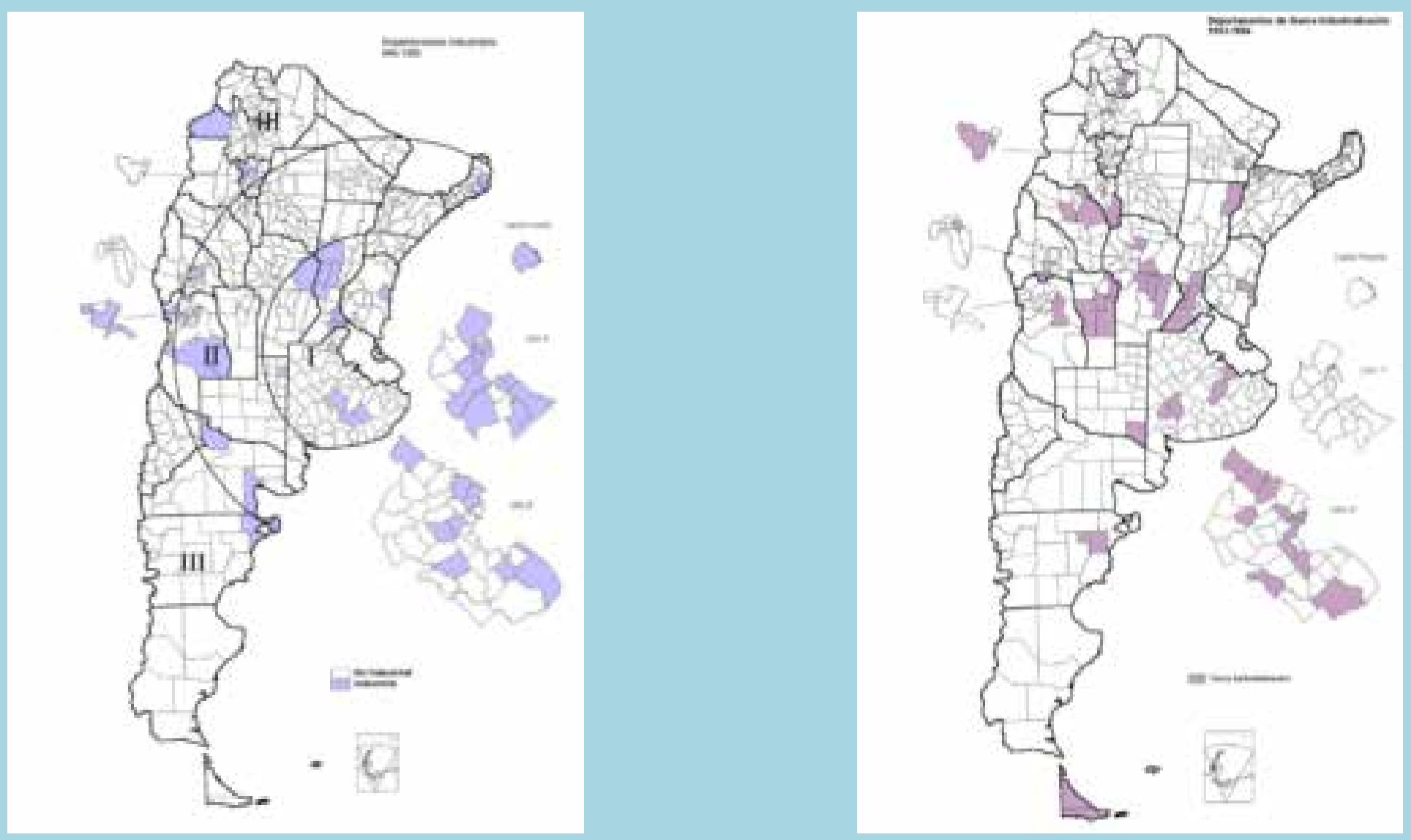

Fuente: Donato, 2007.

Publicado en formato digital: Prof. María del Mar Solís Carnicer, Lic. Silvia Castelán, Prof. Mayra Maggio, Prof. Aníbal M. Mignone y Prof. Alejandra H. Torre Geraldi. El desarrollo industrial en la Argentina. Análisis desde la Historia y la Geografía. Producción en docencia. Revista Geográfica Digital. IGUNNE. Facultad de Humanidades. UNNE. Año 13. № 26. Julio - Diciembre 2016. Resistencia, Chaco. En: http://hum.unne.edu.ar/revistas/geoweb/default.htm 


\section{Participación de los sectores en el producto bruto industrial}

\begin{tabular}{|l|c|c|c|c|c|}
\hline \multicolumn{1}{|c|}{ Productos } & 1900 & $1970-79$ & 1985 & 1990 & 2000 \\
\hline Alimentos, bebidas y tabaco & 43 & 16 & 24,7 & 26,5 & 26,5 \\
\hline Textiles (incluye vestimenta y cuero) & 23 & 12 & 15,5 & 9,4 & 10,1 \\
\hline Industrias de la madera & 10,5 & 1 & 4,7 & 1 & 6,5 \\
\hline Celulosa, papel, imprenta y editoriales & 4 & 4 & 5,5 & 5,3 & 7,4 \\
\hline Productos químicos & 7,5 & 20 & 11,7 & 19,8 & 24,7 \\
\hline Industrias minerales no metalíferos & 9 & 4 & 5,8 & 4 & 3,2 \\
\hline Industrias metalíferas básicas & 2 & 6 & 4,1 & 8,7 & 7,6 \\
\hline Maquinaria, equipos y vehículos & 0,6 & 33 & 27,4 & 18,4 & 13,9 \\
\hline Otras industrias manufactureras & 0,4 & 4 & 0,6 & 6,9 & 0,1 \\
\hline
\end{tabular}

Fuente: Carlevari, 2006

Publicado en formato digital: Prof. María del Mar Solís Carnicer, Lic. Silvia Castelán, Prof. Mayra Maggio, Prof. Aníbal M. Mignone y Prof. Alejandra H. Torre Geraldi. El desarrollo industrial en la Argentina. Análisis desde la Historia y la Geografía. Producción en docencia. Revista Geográfica Digital. IGUNNE. Facultad de Humanidades. UNNE. Año 13. № 26. Julio - Diciembre 2016. Resistencia, Chaco. En: http://hum.unne.edu.ar/revistas/geoweb/default.htm 


\section{Etapa posterior a 2001: Reestructuración?? Postconvertibilidad??}

- Nuevo tipo de cambio.

- Acuerdos con países del Mercosur.

- Dificultades en el matriz energética.

- Crece la actividad industrial pero no hay desarrollo.

- Núcleo duro y con mayor dinámica: industria alimenticia, metalmecánica, siderurgia y el sector automotriz.

- Sigue siendo importante la actividad agroindustrial y la química.

- En la estructura industrial: se profundiza la concentración y la extranjerización.

Fuente: Kulfas y Schorr, 2002; Schorr y Wainer, 2014

Publicado en formato digital: Prof. María del Mar Solís Carnicer, Lic. Silvia Castelán, Prof. Mayra Maggio, Prof. Aníbal M. Mignone y Prof. Alejandra H. Torre Geraldi. El desarrollo industrial en la Argentina. Análisis desde la Historia y la Geografía, Producción en docencia. Revista Geográfica Digital. IGUNNE. Facultad de Humanidades. UNNE. Año 13. № 26. Julio - Diciembre 2016. Resistencia, Chaco. En: http://hum.unne.edu.ar/revistas/geoweb/default.htm 


\section{Parques industriales}

- Se localizan en la periferia de las principales ciudades.

- Áreas delimitadas con administración central.

- Servicio de infraestructura básica para el desarrollo de la producción.

- Accesibilidad.

- Planificación estatal 0 privada.

- Cumplimiento Normas ISO.

- Un total de 300 parques industriales existen actualmente en la Argentina.

- El $\mathbf{5 0 \%}$ de los parques se encuentra en la provincia de Buenos Aires.

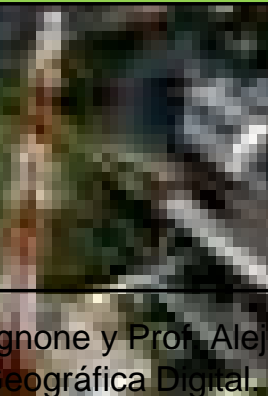




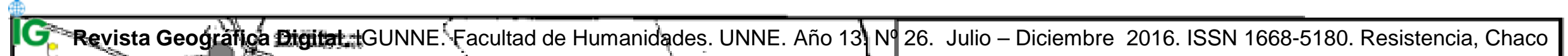

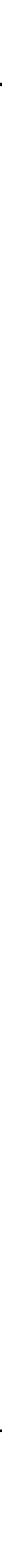




\section{Provincias Pampeanas}

Provincia de Buenos Aires

- Variedad de industrias en las ciudades del interior de la provincia de Buenos Aires.

- Mar del Plata: industria pesquera y textil.

- Bahía Blanca: polo petroquímico.

- Campana: siderurgia

\section{Entre Ríos}

- Molinos arroceros, jugos cítricos, aceiteras, lácteos, papel.

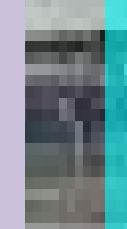

\section{Córdoba}

- La capital concentra gran variedad de industrias: automotriz, motores, aceiteras, frigoríficas, lácteos.

- Villa María, Río Cuarto y San Francisco: agroindustrias.

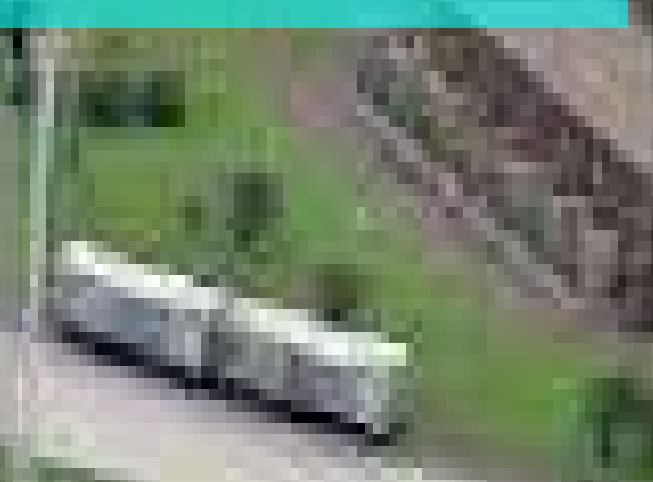

\section{Santa Fe}

- Maquinarias agrícolas.

- Rosario: numerosas industrias: aceiteras, frigoríficas, alimentarias, químicas, papeleras, metalmecánicas.

- Villa Constitución: siderurgia.

- Reconquista y Avellaneda: transformación de productos agrícolas.

- Rafaela: lácteos.

- San Lorenzo: petroquímica. 


\section{Gran Córdoba}

- Se perfila como un polo de alta tecnología desde 2001 (instalación de Motorola).

- Se instalan más de 200 empresas relacionadas con servicios de alta tecnología.

- Construcción del Parque Tecnológico.

- Proyecto de "Tecnópolis"

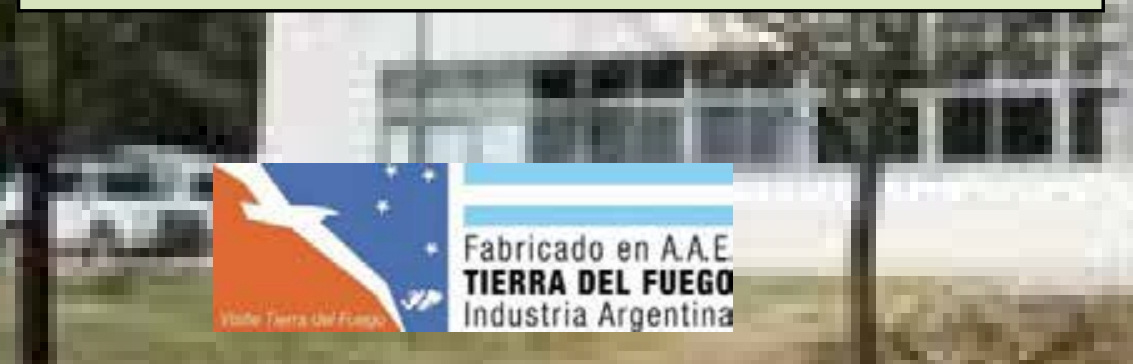

Fuente: Pujol, 2006; Carlevari, 2006; Imagen obtenida de SinM ordaza.com. 18/ 12/ 2015

\section{Tierra del Fuego}

-1982-83 se instala la mayoría de los establecimientos industriales.

-Industria electrónica de ensamble requiere mayor calificación de personal. Atrae población urbana (diferente a otras actividades).

-Industria electrónica 2/ 3 del empleo.

- Luego de la convertibilidad, auge inusitado del turismo, especialmente externo.

-2009: relanzamiento de la industria electrónica, especialmente para Río Grande (perfil industrial). 


\section{Provincias del NEA}

\section{Se destacan las manufacturas con procesamiento de materias primas}

\section{Chaco}

Agroindustria del algodón y del

tanino.

Aceiteras, bebidas gaseosas, madereras.
Corrientes

Alimenticios y bebidas.

Agroindustria del tabaco, yerba mate, té.

Procesamiento de arroz y cítricos. Industria de la madera.

Algodón.

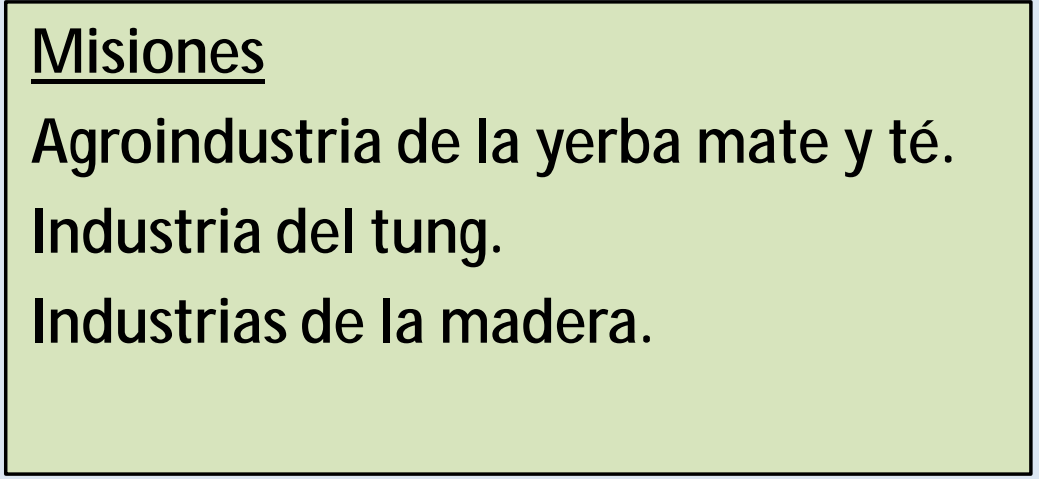

Formosa

Agroindustria del algodón y del arroz. Industria de la madera, del tanino. Aceiteras. 


\section{Actividad industrial por regiones}

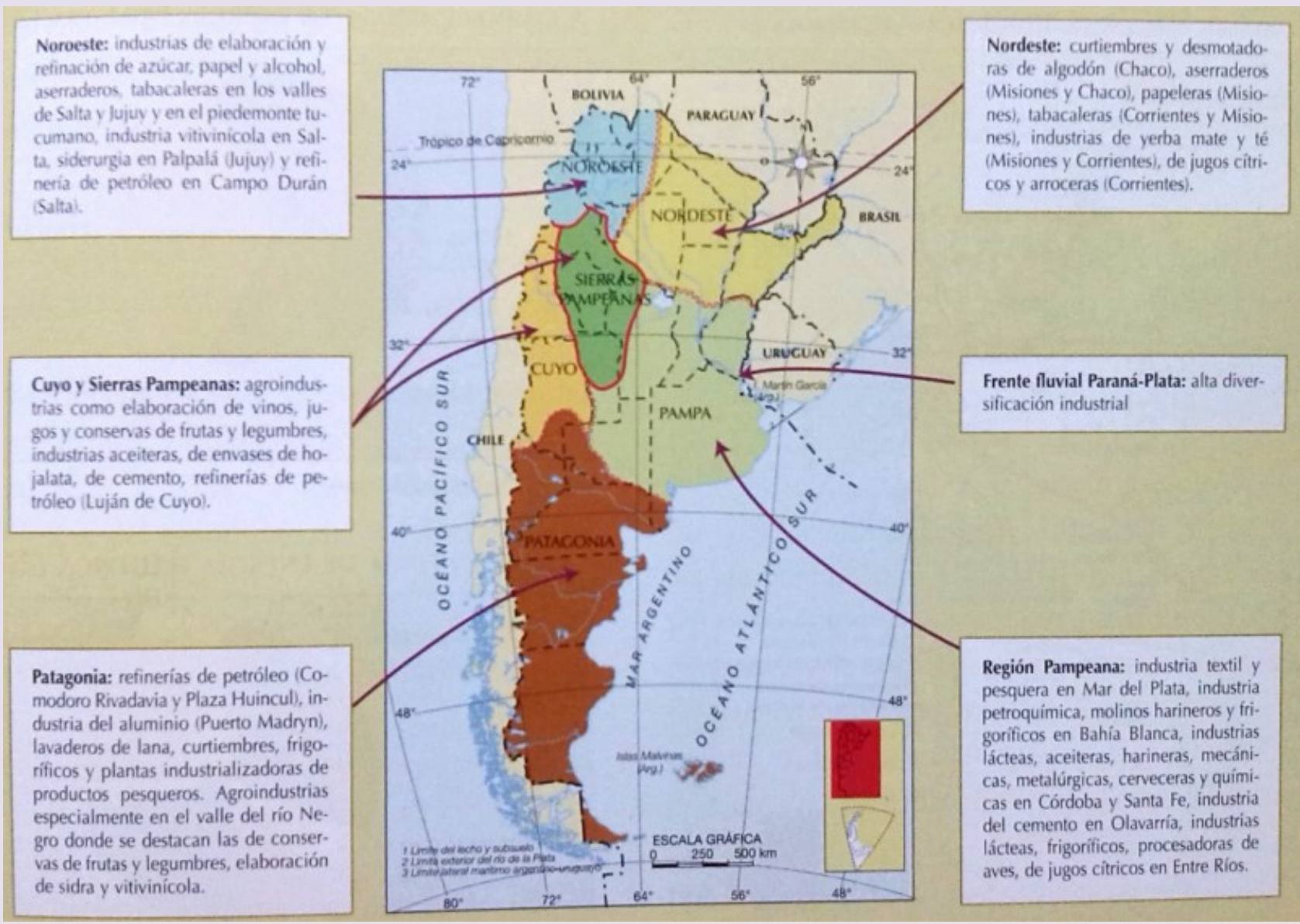

Fuente: Echeverría y Capuz, 2014:129.

Publicado en formato digital: Prof. María del Mar Solís Carnicer, Lic. Silvia Castelán, Prof. Mayra Maggio, Prof. Aníbal M. Mignone y Prof. Alejandra H. Torre Geraldi. El desarrollo industrial en la Argentina. Análisis desde la Historia y la Geografía. Producción en docencia. Revista Geográfica Digital. IGUNNE. Facultad de Humanidades. UNNE. Año 13. № 26. Julio - Diciembre 2016. Resistencia, Chaco. En: http://hum.unne.edu.ar/revistas/geoweb/default.htm 
- Belini, Claudio y Korol, Juan Carlos.2012. Historia económica de la Argentina en el siglo XX. Buenos Aires, Editorial Siglo XXI.

- Bruniard, Enrique. 1979. "El Gran Chaco Argentino. (Ensayo de interpretación geográfica)". En: Geográfica 4. Instituto de Geografía, UNNE.

- Carlevari, Isidro. 2013. La Argentina. Geografía humana y económica, 13ª . Ed. Buenos Aires, Grupo Guía S.A

\section{Bibliografía}

- Crovetto, Norberto. 2008. "Actividades económicas y reconversión productiva. Los cambios en la base económica, en la estructura social y en la organización espacial". En Rocatagliatta (coord.). Argentina. Una visión actual y prospectiva desde la dimensión territorial. Emecé Editores S.A., Buenos Aires, 269-284.

- Diccionario2. 2013. Sistemas de producción. 8 de agosto de 2013. Disponible en Internet: http://mejiaecheverrikevin6.blogspot.com.ar/2013 08 01_archive.html

- Donato, Vicente N. 2007. "Políticas públicas y localización industrial en Argentina”. En: Revista OIDLES (Observatorio Iberoamericano del Desarrollo Local y la Economía Social). Vol. 1, № 0: 351- 385.Abril -Junio de 2007. Universidad de Málaga. Disponible en Internet: $\mathrm{http}: / /$ www.eumed.net/rev/oidles/00/Donato.htm

- Dozo, Servando. 1992. "Industria no integrada y concentrada con desarrollo interrumpido". En: Roccatagliata (coord.). 2da.ed. La Argentina. Geografía general y los marcos regionales. Buenos Aires, Planeta, 311-327.

- Echeverría, M aría J. y Capuz, Silvia M. 2000. Geografía La Argentina y el Mercosur. Serie Polimodal. Buenos Aires, A-Z Editora. Pag: 245.

- Echeverría, M aría J. y Capuz, Silvia M . 2012. Geografía de la Argentina. Serie Plata. Editorial A-Z Editora. $2^{\circ}$ ed. $1^{\circ}$ reimpr. Ciudad Autónoma de Buenos Aires. Pag: 129.

- Economía de la Empresa. Blog del departamento de Economía. 2015. Investigación sobre teorías de la organización. IES Cortes de Cádiz, El M olar, España. Jueves 29 de octubre de 2015. Disponible en Internet: http://economiacdc2.blogspot.com/2015 1001 archive.html.

- Gerchunoff, Pablo y Llach, Lucas. 2000. El ciclo de la ilusión y el desencanto. Un siglo de políticas económicas argentinas. Buenos Aires, Editorial Planeta.

- Gómez Insausti, 2001. "Capitalismo argentino: renovación, hegemonía social y territorio". En: Anales de la Sociedad Argentina de Estudios Geográficos. Tomo 21 - 22 I: 275 - 302. GAEA, Buenos Aires

- Iprofesional.com. 2016. Los parques industriales crecerán un 20\% en 2016. 12 de M ayo de 2016. Buenos Aires. Disponible en Internet: http://www.iprofesional.com/notas/232322-Losparques-industriales-crecern-un-20-por-ciento-en-2016

- Kulfas, Matías y Schorr, Martín. 2002. “La industria argentina en el escenario postconvertibilidad”. En: Realidad Económica N 190. IADE. Disponible en Internet: http://publicacioneseconomia.flacso.org.ar/images/pdf/84.pdf

- Manzanal, M abel y Rofman, Alejandro. 1989. Las economías regionales Crisis y políticas de Desarrollo. Centro Editor de América Latina. Centro de Estudios Urbanos y Regionales, Buenos Aires.

- Meichtry. 1999. "Integración, fronteras y movilidad espacial de la población". En: Folia Histórica del Nordeste 14. IIGHI, Conicet, Resistencia.

- Negro, Juana I. 1982. Geografía Política y Económica de la República Argentina. Editorial Kapelusz, Buenos Aires.

- Peláez, Alberto. 1997. "Cambios recientes en el proceso de desarrollo capitalista. La desregulación y su impacto en el territorio". En: Rocatagliatta, J (coord.). Geografía económica Argentina. Editorial El Ateneo, Buenos Aires. 145-151.

- Pujol, Andrea. 2006. "Evolución reciente del sector software y servicios informáticos. La experiencia en Córdoba”. En: Yoguel, Gabriel. La informática en la Argentina. Desafío a la especialización y la competitividad. Consultado el 02e mayo de 2016. Editorial Prometeo, Buenos Aires. Disponible en Internet: http://www.littec.ungs.edu.ar/SSI2004/6 \%20Pujol.pdf

- Romero M anoukian, Lucas. 2015. "Cuántos parques industriales hay en Argentina”. En: La Economía online. 19 de enero de 2015. Consultado el 22 de abril de 2016. Disponible en internet: http://www.laeconomiaonline.com/2015/01/19/cuantos-parques-industriales-hay-en-argentina/

- Schorr, Martín y Andrés Wainer. 2014. Restricción externa en la Argentina: una mirada estructural de la posconvertibilidad. Programa de "Desigualdad y Democracia", Fundación Heinrich Böll. Consultado el 03 de abril de 2016. Disponible en Internet: http:// www.idaes.edu.ar/pdf papeles/Schorr\%20y\%20Wainer\%20Economia.pdf

- Schvarzer, Jorge. 1987. Promoción industrial en Argentina. Documentos del CISEA N 90. Consultado el 24 de marzo de 2015. Disponible en Internet: http://www.econ.uba.ar/www/institutos/cisea/catalago/archivos/90.pdf

Publicado en formato digital: Prof. María del Mar Solís Carnicer, Lic. Silvia Castelán, Prof. Mayra Maggio, Prof. Aníbal M. Mignone y Prof. Alejandra H. Torre Geraldi. El desarrollo industrial en la Argentina. Análisis desde la Historia y la Geografía. Producción en docencia. Revista Geográfica Digital. IGUNNE. Facultad de Humanidades. UNNE. Año 13. № 26. Julio - Diciembre 2016. Resistencia, Chaco. En: http://hum.unne.edu.ar/revistas/geoweb/default.htm 
- Schvarzer, Jorge. 1996. La industria que supimos conseguir. Una historia político-social de la industria argentina. Buenos Aires, Planeta.

- Zarrilli, Andrés. 2000. "Transformación ecológica y precariedad económica en una economía marginal. El Gran Chaco argentino, 1890-1950". Presentado en XXII International Congress of the Latin American Studies Association, Miami, Florida. 16-18 de marzo de 2000. En: Revista THEOMAl. Estudios sobre Sociedad, Naturaleza y Desarrollo. Número 1 (primer semestre de 2000). Consultado el 14 de septiembre de 2015. Disponible en Internet: http://revistatheomai.unq.edu.ar/numero1/artzarrilli1.htmi

\section{Bibliografía de las imágenes consultadas:}

- $\quad$ Agustín Tosco. Consultado el 01 de mayo de 2016. Disponible en Internet: http:// www.elortiba.org/atosco2.jpg

- $\quad$ Aliaga, Jorge. S/f. La noche de los bastones largos. En: Educ.ar. Consultado el 02 de mayo de 2016. Disponible en Internet: http://repositorioimagendownload.educ.ar/repositorio/Imagen/ver?image id =9e014369-ee9d-4f8a-9c56-9b74b42d89be

ANRed. Agencia.de.Noticias.Redacción. 2009. Desalojaron a trabajadores de la Cooperativa textil Quilmes. 14 de agosto de 2009 . Consultado el 12 de febrero de 2016 . Disponible en Internet: http:// www.anred.org/spip.php?article3108; http://www.anred.org//M G/jpg/DSC06188.jpg

Asociación Civil por la Igualdad y la Justicia (ACIJ). Sin corrupción. 2012. Breve comentario al fallo de acceso a la información sobre los decretos militares secretos. 10 de diciembre de 2012. Consultado el 12 de abril de 2016. Disponible en Internet: http://acij.org.ar/sin-corrupcion/2012/wp-content/uploads/2012/12/guille037Primera] untaM ilitar19761.jpg Central de Trabajadores de la Argentinca (CTA). 2015. Anuncian el programa para el reordenamiento de la Economía Nacional. 18 de diciembre de 2015 . Consultado el 11 de abril de 2016. Disponible en Internet: http:// www.cta.org.ar/IM G/jpg/tapa completa clari n 1977.jpg

Dávila, Diego. 2011. El largo camino hacia la electrónica nacional. En: La Voz Édición Digital. 03 de julio de 2007. Consultado el 05 de septiembre de 2015. Disponible en Internet: http://staticf5b.lavozdelinterior.com.ar/sites/default/files/styles/landscape_1008_566/public/archivo/nota_periodistica/negocios2.jpg El historiador.com. S/f. Galerías del Bicentenario. 1925-1950. Consultado el 03 de mayo de 2016. Disponible en Internet: http:// www.elhistoriador.com.ar/imagenes rapido/19251949/images/big/1930-002.jpg

El sur del sur. Argentina el país su cultura y su gente. S/F. Argentina: actividades económicas. Consultado el 27 de abril de 2016 . Disponible en Internet: http://surdelsur.com/es/wpcontent/uploads/sites/2/2014/11/ae04hi-industria-automotriz.jpg

Esa vieja cultura frita. Blog. S/f. Consultado el 07 de abril de 2016. Disponible en Internet: http://esaviejaculturafrita.blogspot.com/2013 0309 archive.htm Hola Palmira. 2016. Aprobaron la venta de YPF (Yacimientos Petrolíferos Fiscales). 06 de febrero de 2016. Consultado el 14 de abril de 2016 . Disponible en Internet: http://www.holapalmira.com.ar/wp-content/uploads/2016/02/Venta-de-ypf.jpg

Informe Industrial. 2012. "De récords y controles". Revista Informe Industrial Versión digital. 17 de enero de 2012 . Consultado el 03 de mayo de 2016. Editorial M ellipal. Buenos Aires. Disponible en Internet: http:// www.informeindustrial.com.ar/imagenes/484 Producci\%C3\%B3n\%20Automotriz.jpg

King \&M CGaw. S/ f. London Herald Art Prints And Posters. Consultado el 03 de mayo de 2016. Disponible en Internet: https://img.kingandmcgaw.com/i/prints/lg/9/8/98537.jpg La economía online. 2012. Economistas del siglo XX. Keynes, Kalecki y Kaldor. 17 de agosto de 2012. Consultado el 05 de mayo de 2016. Disponible en Internet: http://www.laeconomiaonline.com/2012/08/17/economistas-k-del-siglo-xx-keynes-kalecki-y-kaldor/

Las imágenes retro. 2011. Julio de 2011. Consultado el 14 de abril de 2016. Disponible en Internet: https://lasimagenesretro.files.wordpress.com/2011/07/pacto-de-olivos.jpg Mágicas ruinas. S/f. Crónicas del siglo pasado. Consultado el 02 de mayo de 2016. Disponible en Internet: http://www.magicasruinas.com.ar/revistero/esto/pinedo2.jpg Serqueiros, Juan Carlos. 2013. Nunca he sido amigo de ese tipo. En: Esa vieja cultura frita. 09 de marzo de 2013. Consultado el $04 d e$ mayo de 2016. Disponible en Internet: http:// esaviejaculturafrita.blogspot.com.ar/2013 0309 archive.html

Sin M ordaza. 2015. Conflicto laboral en TenarisSiderca, de Techint. En: SinMordaza.com. 18 de diciembre de 2015. Consultado el 10 de mayo de 2016. Disponible en Internet: http://www.sinmordaza.com/imagesnueva/noticias/grandes/130559 empresarias.jpg

Taringa.Net. S/f. Fábrica de armas. Consultado el 30 de abril de 2016. Disponible en Internet: http://s4.postimg.org/tbkaa28cd/Obraz_084.jpg

Tematika.com. La Teoría general del empleo, el interés y el dinero. S/f. Consultado el 03 de mayo de 2016. Disponible en Internet:http://www.tematika.com/tapas/sitio/502628c0.jpg Todo Argentina. S/f. Presidencia de Videla (1976-1981). Consultado el 03 de mayo de 2016. http:// www.todo-argentina.net/historia/ civmil/videla/ imagenes/joe2.jpgf

Wikipedia.com. S/F. Juan Perón. Consultado el 29 de abril de 2016. Disponible en Internet:

https://en.wikipedia.org/wiki/Juan Per\%C3\%B3n\#/media/File:Juan Domingo Per\%C3\%B3n.jpg

Wikipedia.com. S/F. Siam Di Tella. Consultado el 27 de marzo de 2016. Disponible en Internet:

https://es.wikipedia.org/wiki/Siam Di Tella\#/media/File:Frente de la f\%C3\%Albrica SIAM en Pi\%C3\%Bleyro.jpg

Wikipedia.org. S/f. Siambretta. Consultado el 18 de febrero de 2016. Disponible en Internet: https://es.wikipedia.org/wiki/Siambretta\#/media/File:Siambretta_48j.jpg

Publicado en formato digital: Prof. María del Mar Solís Carnicer, Lic. Silvia Castelán, Prof. Mayra Maggio, Prof. Aníbal M. Mignone y Prof. Alejandra H. Torre Geraldi. El desarrollo industrial en la Argentina. Análisis desde la Historia y la Geografía, Producción en docencia. Revista Geográfica Digital. IGUNNE. Facultad de Humanidades. UNNE. Año 13. № 26. Julio - Diciembre 2016. Resistencia, Chaco. En: http://hum.unne.edu.ar/revistas/geoweb/default.htm 